\title{
Anti-cancer and Antimicrobial Activity, In-Silico ADME and Docking Studies of Biphenyl Pyrazoline Derivatives
}

\author{
Raja Chinnamanyakar ${ }^{1}$ (D), Ezhilarasi Muthuvel Ramanathan ${ }^{1, *}$ \\ 1 Department of Chemistry, Karpagam Academy of Higher Education, Coimbatore-21, TamilNadu, India \\ * Correspondence: mrezhilarasi@gmail.com;
}

Scopus Author ID 14043431700

Received: 24.06.2020; Revised: 16.07.2020; Accepted: 18.07.2020; Published: 22.07.2020

\begin{abstract}
The present study deals with the multicomponent Michal addition reaction of xenyl chalcone (10-17) reacting with hydrazine hydrate in the presence of ethane carboxylic acid. It afforded new pyrazoline compounds. The propane pyrazoline derivatives (18-25) skeleton structure was confirmed by spectral studies like Fourier-Transform Infrared spectroscopy, ${ }^{1} \mathrm{H}$ NMR, ${ }^{13} \mathrm{C}$ NMR, and CHN analysis. The adsorption, distribution, metabolism, and excretion (ADME) properties of the synthesized molecules were investigated. The results obtained in-silico demonstrated that these molecules could be considered as orally active drug candidates due to their physical and chemical properties. The compounds (18-25) were subjected to docking prediction studies by protein (1UAG) and breast cancer protein (1OQA). While Comparing with the drug ciprofloxacin, among the series of eight compounds (18-25), compound 19, 20, and 24 have the best binding affinity score $(-8.5 \mathrm{kcal} / \mathrm{mol})$. We have selected only the compound 21 (4- $\mathrm{Cl}$ (electronegativity group)) compound for MTT assay of breast cancer cell line studies because it has the best binding affinity score in the binding study of the compound with 1OQA protein. Synthesized pyrazoline compound (18-25) also obeys the Lipinski rule of five and other criteria of drug-likeness properties. Among the synthesized pyrazoline compound (18-25), especially compound 21 (electronegativity group (4-Cl) has the best drug-likeness property and has a value of 7.16. Furthermore, antimicrobial activity of these compounds has been evaluated against five microbial strains, and from this result, some of the newly synthesized compounds exhibit good activity.
\end{abstract}

Keywords: Xenyl chalcone; Hydrazine hydrate; Ethane carboxylic acid; In-silico study; ADME property; Anti-cancer activity (MDA MB-231 Cell line).

(C) 2020 by the authors. This article is an open-access article distributed under the terms and conditions of the Creative Commons Attribution (CC BY) license (https://creativecommons.org/licenses/by/4.0/).

\section{Introduction}

Cancer is a disease caused by abnormal cell growth in the human body. Cancer is a common disease, which is the second leading cause of death in humans. It is mainly caused by way of using tobacco, obesity, excessive drinking alcohol, and lack of physical activities. In some cases, cancer arises due to infections such as hepatitis B, hepatitis C, Epstein-Bars virus, human papillomavirus, and HIV. The formation of the malignant tumor in the breast is called breast cancer. This takes place in both males and females, but men breast cancer is a limited one. The most dangerous death disease that is affected by Indian women is Breast cancer [1]. The breast cancer cells spread through a process known as cancer metastasis. Through the process, organs like the liver, lungs, brains, and bones get affected, and it causes a major problem for survival. In a pathetic condition from nearly 1, 735, 350 cancer cases, deaths of nearly 609, 640 are projected to occur in the US in 2018 [2]. There are different types of cancer treatment that depends upon the cancer type and the affected stage of the patients. A most 
important method for the treatment is chemotherapy, radiation therapy, targeted therapy, and hormonal therapy [3]. Chemotherapy plays a vital role in treatment therapeutics. However, it has its own limitation like limited efficiency, selectively, high cast, genotoxicity, and drug resistance [4]. Many therapies were introduced in recent years to deal with the recurrence of cancer, but the medicines and drugs have their own side effects on an affected person. Extensive research in the field of developing new drugs, especially in the designing and discovery of the anti-cancer agents, is needed for the present day [5,6].

Generally, very well known compounds containing heterocyclic ring systems are most important in both industry field and medicinal field [7]. Heterocyclic compounds posses to be most effective against various cancers [8]. Pyrazole derivatives are the most important fivemember heterocyclic compound, and these types of compounds only gave more attention in the field of Pharmaceutical and agriculture $[9,10]$. The heterocyclic compounds containing pyrazole ring have a versatile lead molecule in medical field, it has showed various biological activities like anticancer [11], antifungal [12, 13], antimicrobial [14-18], anti-tubercular [19, 20], antibacterial [21] and antidepressant [22], antidiabetic [23], antioxidant[24]. Also, Pyrazole compounds are products that have given encouraging results towards the inhibition of the corrosion of several metals[25-28].

Computer models provide information about the possible effects of the compounds on metabolism and whether they are suitable for being used as medicine without performing experimental studies. Cheminformatics allows us to understand its pharmacokinetics, physical, chemical, solubility, adsorption, and similar properties from the chemical structure of a molecule. Many new molecules are synthesized every year in the world. Test the bioactivity of these molecules as in-vivo and in-vitro results manifest very expensive. Therefore, ADME and predicting the targets of the molecule have become essential for those sectors in which these molecules can be used [29, 30]. Structure-based drug designing and; Ligand-based drug designing techniques are employed as important drug discovery tools in rational drug discovery process [31,32]. Docking studies is the advanced computational methods in structure-based drug designing to obtain optimized conformation of Ligand-receptor interaction and to study their relative orientation through the minimized energy-free system[33]. Computer-aided drug design is fast, economically modernized techniques that give valuable, accurate, and deep understandings of experimental findings and new suggestions for molecular structures to be synthesized[34].

In continuation of our research work in this paper, we present the novel and newly synthesized compounds (18-25). Synthesized compounds (18-25) chemical structures were confirmed by Infra-Red, Proton, and Carbon NMR spectroscopic CHN analysis. In-silico studies were carried out by 1 UAGand 1OQA protein, which was collected by the PDB (Protein data bank). According to the docking predictions, only one compound gave the best binding interaction score, so that the particular compound 21 was studied for cancer activity. Furthermore, microbial evaluation and in-silico ADME property were also studied in synthesized propane pyrazoline derivatives.

\section{Materials and Methods}

\subsection{General methods.}

Melting points (uncorrected) were measured on MELT TEMP melting point instrument. The infra spectra were recorded in $\mathrm{KBr}$ pellet on a Shimadzu FT-IR spectrometer 
(not all frequencies are reported). ${ }^{1} \mathrm{H}$ NMR and ${ }^{13} \mathrm{C}$ NMR spectra were measured on a BRUCKER $400 \mathrm{MHz}$ NMR spectrometer in $\mathrm{CDCl}_{3}$ with TMS as an internal standard at room temperature. All the reactions were monitored by TLC, which was carried out on Merck silica gel coated on plates. Laboratory grade chemicals and solvents available commercially in highgrade purity were used. All the synthesized compounds were identified by physical properties, IR, NMR, Anticancer studies, Antimicrobial studies, and Elemental analysis. Elemental analysis was carried out on Perkin Elmer 2400 analyzer. Anti-cancer studies were carried out at Biogenic Research Center. Thiruvanandapuram. By adopting the literature precedent, the 1(3-aryl-5-biphenyl- propane-1-ones (10-17) were prepared [5].

\subsection{Synthesis of 1(3-biphenyl-5-aryl)-4, 5-dihydropyrazol-1-yl)propan-1-ones (18-25).}

To $0.01 \mathrm{~mol}$ of Chalcone (12-21), $0.01 \mathrm{~mol}$ of hydrazine hydrate and $30 \mathrm{ml}$ of propionic acid were taken in the Round Bottom flask. Then the mixture was refluxed for 14-16 $\mathrm{h}$. The reaction was monitored by TLC using $100 \% \mathrm{CHCl}_{3}$. After that, it was poured into $500 \mathrm{~mL}$ beaker containing ice cubes, and then it was kept in to overnight at room temperature. The solid products were precipitated out. It was filtered, dried, and recrystallized from rectified spirit. The purity was checked by TLC by 9:1 ratio (P.E + E.A) [5].

1(3-biphenyl-5-phenyl)-4, 5-dihydropyrazol-1yl) propan-1one (18).

Colour:White solid; $\mathrm{mf} \mathrm{C}_{24} \mathrm{H}_{22} \mathrm{~N}_{2} \mathrm{O}$; Elem. Anal. Found; C, 81.33; H, 6.26; N, 7.90; O, 4.51. Cal. C, 81.32; H, 6.20; N, 7.89; O, 4.51; IR (KBr, cm $\left.{ }^{-1}\right) 1657.32(\mathrm{C}=\mathrm{O}), 1579.41(\mathrm{C}=\mathrm{N})$, $1405.85(\mathrm{C}-\mathrm{N}), 3072.05$ (Ar-CH), 534.18, 692.32, 841.77. ${ }^{1} \mathrm{H} \mathrm{NMR}\left(\mathrm{CDCl}_{3}, 400 \mathrm{MHz}\right): 1.18-$ $1.21\left(\mathrm{CH}_{3}, 3 \mathrm{H}\right), 2.80-2.86\left(\mathrm{~m},-\mathrm{CH}_{2}-4 \mathrm{H}\right), 3.14(\mathrm{dd}), \mathrm{H}-4 \mathrm{a}, \mathrm{J}$ 4a, 4e $=4.6 \mathrm{~Hz} \& \mathrm{~J}$ 4a, 5a $=17.8 \mathrm{~Hz}$; 3.77 (dd), H-4e, J 4e, 4a $=12 \mathrm{~Hz} \& \mathrm{~J}_{4 \mathrm{e}, 5 \mathrm{a}}=18 \mathrm{~Hz} ; 5.54$ (dd), H-5a, J 5a, 4a $=4.4 \mathrm{~Hz} \& \mathrm{~J}_{5 \mathrm{a}, 4 \mathrm{e}}=$ 11.6 Hz; 7.11-7.81 (Ar-H). ${ }^{13} \mathrm{C} \mathrm{NMR}\left(\mathrm{CDCl}_{3}, 400 \mathrm{MHz}\right): 172.42(\mathrm{C}=\mathrm{O}), 153.26(\mathrm{C}=\mathrm{N}), 41.97$ (C-4), 59.63 (C-5), 27.60 (-CH $2-), 8.98\left(\mathrm{CH}_{3}\right), 121.55-130.20$ (Ar-C), 143.14, 141.12, 140.10, 132.05 (Ipso carbon).

1(3-biphenyl-5-(4-bromophenyl)-4, 5-dihydropyrazol-1-yl)propan-1-one(19).

Colour: White solid; mf $\mathrm{C}_{24} \mathrm{H}_{21} \mathrm{BrN}_{2} \mathrm{O}$. Elem. Anal. Found; C, 66.52; H, 4.88; $\mathrm{Br}$, 18.44; N, 6.46; O, 3.69; Cal. C, 66.46; H, 4.84; Br, 18.41; N, 6.46; O, 3.69; IR (KBr) 1653.71 $(\mathrm{C}=\mathrm{O}), 1563.11(\mathrm{C}=\mathrm{N}), 1413.09(\mathrm{C}-\mathrm{N}), 3088.37(\mathrm{Ar}-\mathrm{CH}), 598.01,633.72,827.99 .{ }^{1} \mathrm{H}$ NMR $\left(\mathrm{CDCl}_{3}, 400 \mathrm{MHz}\right): 1.18-1.21\left(\mathrm{CH}_{3}, 3 \mathrm{H}\right), 2.80-2.84\left(\mathrm{~m},-\mathrm{CH}_{2-}\right), 3.16(\mathrm{dd}), \mathrm{H}-4 \mathrm{a}, \mathrm{J}$ 4a, 4e $=4.8$

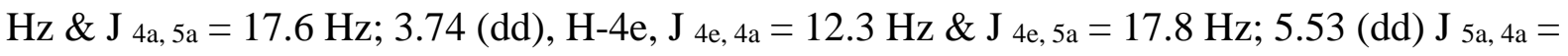
$4.5 \mathrm{~Hz} \& \mathrm{~J}_{5 \mathrm{a}, 4 \mathrm{e}}=11.8 \mathrm{~Hz} ; 6.91-7.80(\mathrm{Ar}-\mathrm{H}) .{ }^{13} \mathrm{C} \mathrm{NMR}\left(\mathrm{CDCl}_{3}, 400 \mathrm{MHz}\right): 171.90(\mathrm{C}=\mathrm{O})$, $152.98(\mathrm{C}=\mathrm{N}), 41.09(\mathrm{C}-4), 58.37(\mathrm{C}-5), 27.67\left(-\mathrm{CH}_{2}-\right), 9.12\left(\mathrm{CH}_{3}\right), 121.87-13.08$ (Ar-C), 144.23, 143.89, 142.21, 140.09 (Ipso carbon).

1(3-biphenyl-5-(4-flurophenyl)-4, 5-dihydropyrazol-1-yl)-propan-1-one(20).

Colour: White solid; $\mathrm{mf} \mathrm{C}_{24} \mathrm{H}_{21} \mathrm{FN}_{2} \mathrm{O}$, Elem. Anal. Found; C, 77.40; H, 5.68; F, 5.10; N, 7.52; O, 4.30; Cal. C, 77.32; H, 5.63; F, 5.10; N, 7.51; O, 4.29; IR (KBr, cm-1) 1653.66 $(\mathrm{C}=\mathrm{O}), 1507.10(\mathrm{C}=\mathrm{N}), 1402.96(\mathrm{C}-\mathrm{N}), 3099.13(\mathrm{Ar}-\mathrm{CH}), 694.24,830.20 .{ }^{1} \mathrm{H} \mathrm{NMR}\left(\mathrm{CDCl}_{3}\right.$, $400 \mathrm{MHz}$ ): 1.18-1.21 ( $\left.\mathrm{CH}_{3}, 3 \mathrm{H}\right), 2.82-2.87$ (m, $\left.-\mathrm{CH}_{2-}, 4 \mathrm{H}\right), 3.14(\mathrm{dd}), \mathrm{H}-4 \mathrm{a}, \mathrm{J}$ a, $4 \mathrm{e}=4.4 \mathrm{~Hz}$ \& $\mathbf{J}_{4 \mathrm{a}, 5 \mathrm{a}}=18.2 \mathrm{~Hz}, 3.76(\mathrm{dd}), \mathrm{H}-4 \mathrm{e}, \mathrm{J}_{4 \mathrm{e}}, 4 \mathrm{a}=12.4 \mathrm{~Hz} \& \mathrm{~J}_{4 \mathrm{e}}, 5 \mathrm{a}=18 \mathrm{~Hz}, 5.55$ (dd), H-5a, J 5a, 4a = $4.8 \mathrm{~Hz} \& \mathrm{~J} 5 \mathrm{a}, 4 \mathrm{e}=11.6 \mathrm{~Hz}, 6.90-7.83(\mathrm{Ar}-\mathrm{H}) .{ }^{13} \mathrm{C} \mathrm{NMR}\left(\mathrm{CDCl}_{3}, 400 \mathrm{MHz}\right), 172.40(\mathrm{C}=\mathrm{O})$, $153.30(\mathrm{C}=\mathrm{N}), 42.10(\mathrm{C}-4), 59.53(\mathrm{C}-5), 27.63\left(-\mathrm{CH}_{2}-\right), 9.02$ (CH3), 125.98- 137.92 (Ar-C), $143.09,140.45,140.32,137.95$ (Ipso carbon).

1(3-biphenyl-5-(4-chlorophenyl)-4, 5-dihydropyrazol-1-yl)propane-1-one (21). 
Colour: White solid; $\mathrm{mf} \mathrm{C}_{24} \mathrm{H}_{21} \mathrm{ClN}_{2} \mathrm{O}$, Elem. Anal. Found; C, 74.12; H, 5.44; Cl, 9.12; N, 7.20; O, 4.11; Cal. C, 74.05; H, 5.39; N, 7.19; O, 4.11; Cl, 9.11; IR (KBr, $\left.\mathrm{cm}^{-1}\right) 1654.62$ $(\mathrm{C}=\mathrm{O}), 1511.92(\mathrm{C}=\mathrm{N}), 1393.32(\mathrm{C}-\mathrm{N}), 3067.56(\mathrm{Ar}-\mathrm{CH}), 527.43,688.46,837.91 .{ }^{1} \mathrm{H}$ NMR $\left(\mathrm{CDCl}_{3}, 400 \mathrm{MHz}\right) ; 1.18-1.21\left(\mathrm{CH}_{3}, 3 \mathrm{H}\right), 2.80-2.85$ (m, - $\left.\mathrm{CH}_{2}-, 4 \mathrm{H}\right), 3.11(\mathrm{dd}), \mathrm{H}-4 \mathrm{a}, \mathrm{J}$ 4a, 4e $=$ $4.4 \mathrm{~Hz} \& \mathrm{~J}_{4 \mathrm{a}}, 5 \mathrm{a}=17.6 \mathrm{~Hz}, 3.73(\mathrm{dd}), \mathrm{H}-4 \mathrm{e}, \mathrm{J}_{4 \mathrm{e}}, 4 \mathrm{a}=11.6 \mathrm{~Hz} \& \mathrm{~J}$ ee, 5a $=18 \mathrm{~Hz}, 5.53$ (dd), H-5a, $\mathrm{J}_{5 \mathrm{a}, 4 \mathrm{e}}=4 \mathrm{~Hz} \& \mathrm{~J} 5 \mathrm{a}, 4 \mathrm{e}=11.6 \mathrm{~Hz}, 7.15-7.80(\mathrm{Ar}-\mathrm{H}) .{ }^{13} \mathrm{C} \mathrm{NMR}\left(\mathrm{CDCl}_{3}, 400 \mathrm{MHz}\right): 172.37$ $(\mathrm{C}=\mathrm{O}), 153.23(\mathrm{C}=\mathrm{N}), 42.01(\mathrm{C}-4), 59.61(\mathrm{C}-5), 27.63\left(-\mathrm{CH}_{2}-\right), 9.02\left(\mathrm{CH}_{3}\right), 126.78-130.25$ (Ar-C), 143.10, 140.64, 140.10, 133.43 (Ipso carbon).

1(3-biphenyl-5-(4-nitrophenyl)-4, 5-dihydropyrazol-1-yl)-propane-1-one (22).

Colour: White solid; $\mathrm{mf} \mathrm{C}_{24} \mathrm{H}_{21} \mathrm{~N}_{3} \mathrm{O}_{3}$, Elem. Anal. Found; C, 72.16; H, 5.30; N, 10.52; O, 12.02; Cal. C, 72.10; H, 5.25; N, 10.51; O, 12.00; IR (KBr, cm $\left.{ }^{-1}\right) 1654.62(\mathrm{C}=\mathrm{O}), 1511.92$ $(\mathrm{C}=\mathrm{N}), 1393.32(\mathrm{C}-\mathrm{N}), 3067.56(\mathrm{Ar}-\mathrm{CH}), 527.43,688.46,837.91 .{ }^{1} \mathrm{H} \mathrm{NMR}\left(\mathrm{CDCl}_{3}, 400 \mathrm{~Hz}\right)$; 1.18-1.21 ( $\left.\mathrm{CH}_{3}, 3 \mathrm{H}\right), 2.80-2.85\left(\mathrm{~m},-\mathrm{CH}_{2}-, 4 \mathrm{H}\right), 3.16(\mathrm{dd}), \mathrm{H}-4 \mathrm{a}, \mathrm{J}_{4 \mathrm{a}}, 4 \mathrm{e}=4.4 \mathrm{~Hz} \& \mathrm{~J}$ 4a, 5a $=17.6$ $\mathrm{Hz}, 3.84$ (dd), H-4e, J 4e, 4a $=11.6 \mathrm{~Hz} \& \mathrm{~J}$ 4e, $5 \mathrm{a}=18 \mathrm{~Hz}, 5.53$ (dd), H-5a, J 5a, 4a $=4 \mathrm{~Hz} \& \mathrm{~J}$ 5a, 4e $=11.6 \mathrm{~Hz}, 7.15-7.80(\mathrm{Ar}-\mathrm{H}) .{ }^{13} \mathrm{C} \mathrm{NMR}\left(\mathrm{CDCl}_{3}, 400 \mathrm{~Hz}\right): 172.53(\mathrm{C}=\mathrm{O}), 153.16(\mathrm{C}=\mathrm{N}), 42.19$ (C-4), 59.66 (C-5), 27.56 (-CH2-), 8.92 ( $\left.\mathrm{CH}_{3}\right), 124.37-129.85$ (Ar-C), 149.09, 147.40, 143.37, 140.01 (Ipso carbon).

1(3-biphenyl-5-(2-chlorophenyl)-4, 5-dihydropyrazol-1-yl)propan-1-one (23).

Colour: White solid; $\mathrm{mf} \mathrm{C}_{24} \mathrm{H}_{21} \mathrm{ClN}_{2} \mathrm{O}$, Elem. Anal. Found; C, 74.12; H, 5.44; Cl, 9.12; N, 7.20; O, 4.11; Cal. C, 74.05; H, 5.39; N, 7.19; Cl, 9.11; O, 4.11; IR (KBr, cm $\left.{ }^{-1}\right) 1659.37$ $(\mathrm{C}=\mathrm{O}), 1554.78(\mathrm{C}=\mathrm{N}), 1419.77(\mathrm{C}-\mathrm{N}), 3059.57(\mathrm{Ar}-\mathrm{CH}) ;{ }^{1} \mathrm{H} \mathrm{NMR}\left(\mathrm{CDCl}_{3}, 400 \mathrm{MHz}\right) ; 1.18$ $1.21\left(\mathrm{CH}_{3}, 3 \mathrm{H}\right), 2.82-2.86\left(\mathrm{~m},-\mathrm{CH}_{2}-, 4 \mathrm{H}\right), 3.12(\mathrm{dd}), \mathrm{H}-4 \mathrm{a}, \mathrm{J} 4 \mathrm{a}, 4 \mathrm{e}=4.6 \mathrm{~Hz} \& \mathrm{~J}$ 4a, 5a $=17.8 \mathrm{~Hz}$, 3.88 (dd), H-4e, J 4e, 4a $=11.8 \mathrm{~Hz} \& \mathrm{~J}$ 4e, $5 \mathrm{a}=18.2 \mathrm{~Hz}, 5.59$ (dd), H-5a, J 5a, 4a $=3.8 \mathrm{~Hz} \&$ J 5a, 4e $=11.3 \mathrm{~Hz}, 7.13-7.76(\mathrm{Ar}-\mathrm{H}) .{ }^{13} \mathrm{C} \mathrm{NMR}\left(\mathrm{CDCl}_{3}, 400 \mathrm{MHz}\right) ; 172.13(\mathrm{C}=\mathrm{O}), 152.99(\mathrm{C}=\mathrm{N})$, 42.37 (C-4), 59.12 (C-5), $27.59\left(-\mathrm{CH}_{2}-\right), 8.93\left(\mathrm{CH}_{3}\right), 126.71-131.53$ (Ar-C), 140.09, 139.87, 139.03, 137.88 (Ipso carbon).

1(3-biphenyl-5( $p$-toly)-4, 5-dihydropyrazol-1-yl)propan-1-one (24).

Colour: White solid; $\mathrm{mf}_{2} \mathrm{C}_{2} \mathrm{H}_{24} \mathrm{~N}_{2} \mathrm{O}$, Elem. Anal. Found; C, 81.49; H, 6.57; N, 7.60; O, 4.34; Cal. C, 81.41; H, 6.51; N, 7.59; O, 4.33; IR (KBr, $\left.\mathrm{cm}^{-1}\right) 1667.88(\mathrm{C}=\mathrm{O}), 1551.03(\mathrm{C}=\mathrm{N})$, 1403.11(C-N), 3051.02 (Ar-CH); ${ }^{1} \mathrm{H} \mathrm{NMR}\left(\mathrm{CDCl}_{3}, 400 \mathrm{MHz}\right) ; 1.24-1.27\left(\mathrm{CH}_{3}, 3 \mathrm{H}\right), 2.87-2.94$ (m, - $\left.\mathrm{CH}_{2-}, 4 \mathrm{H}\right), 3.08$ (dd), H-4a, J 4a, 4e = $3.8 \mathrm{~Hz} \& \mathrm{~J}$ 4a, 5a $=17.8 \mathrm{~Hz}, 3.85$ (dd), H-4e, J 4e, 4a = $12.4 \mathrm{~Hz}, \mathrm{~J}$ 4e, $5 \mathrm{a}=17.2 \mathrm{~Hz}, 5.94$ (dd), H-5a, J 5a, 4a = 4.4 Hz \& J 5a, 4e = 12Hz, 7.07-7.81 (ArH). ${ }^{13} \mathrm{C} \mathrm{NMR}\left(\mathrm{CDCl}_{3}, 400 \mathrm{MHz}\right) ; 172.34(\mathrm{C}=\mathrm{O}), 153.67(\mathrm{C}=\mathrm{N}), 41.21(\mathrm{C}-4), 57.79(\mathrm{C}-5), 27.60$ (-CH2-), 127.07-130.29 (Ar-C), 143.06, 140.13, 138.74, 131.77 (Ipso carbon).

1(3-biphenyl-5-(4-methoxy phenyl)-4, 5-dihydropyrazol-1-yl)-propan-1-one (25).

Colour: White solid; $\mathrm{mf} \mathrm{C}_{25} \mathrm{H}_{24} \mathrm{~N}_{2} \mathrm{O}_{2} ; \mathrm{C}, 78.10 ; \mathrm{H}, 6.29 ; \mathrm{N}, 7.29 ; \mathrm{O}, 8.32$; Cal. C, 78.02; $\mathrm{H}, 6.24$; N, 7.28; O, 8.31; IR ( $\left.\mathrm{KBr}, \mathrm{cm}^{-1}\right) 1654.62(\mathrm{C}=\mathrm{O}), 1511.92(\mathrm{C}=\mathrm{N}), 1425.14(\mathrm{C}-\mathrm{N})$, 3033.18 (Ar-CH), 531.29, 767.53, 858.16. ${ }^{1} \mathrm{H} \mathrm{NMR}\left(\mathrm{CDCl}_{3}, 400 \mathrm{MHz}\right) ; 1.18-1.21\left(\mathrm{CH}_{3}, 3 \mathrm{H}\right)$, 280-2.85 (m, - $\left.\mathrm{CH}_{2-}, 4 \mathrm{H}\right), 3.15$ (dd), H-4a, J 4a, 4e $=4 \mathrm{~Hz} \& \mathrm{~J}$ 4a, 5a = $17.6 \mathrm{~Hz}, 3.72$ (dd), H-4e, J $4 \mathrm{e}, 4 \mathrm{a}=12.2 \mathrm{~Hz} \& \mathrm{~J}$ 4e, 5a $=17.4 \mathrm{~Hz}, 5.55$ (dd) H-5a, J 5a, 4a $=4.2 \mathrm{~Hz} \& \mathrm{~J}$ 5a, 4e $=11.4 \mathrm{~Hz}, 7.07-$ $7.81(\mathrm{Ar}-\mathrm{H}) .{ }^{13} \mathrm{C} \mathrm{NMR}\left(\mathrm{CDCl}_{3}, 400 \mathrm{MHz}\right) ; 172.26(\mathrm{C}=\mathrm{O}), 153.26(\mathrm{C}=\mathrm{N}), 42.15(\mathrm{C}-4), 59.98$ (C-5), 27.64 (- $\left.\mathrm{CH}_{2}-\right), 9.05\left(\mathrm{CH}_{3}\right), 125.60-130.55$ (Ar-C), 142.91, 140.20, 139.25, 137.31 (Ipso carbon). 


\subsection{In-silico activity.}

2.3.1. Molecular docking studies.

Docking studies have been carried out by the Auto dock Tools (ADT) version 1.5.6 and Auto dock version 4.2.5.1 docking program. The proteins were downloaded from PDB file. The reference method was followed for the docking study [35-37].

\subsubsection{In-silico ADME prediction.}

Absorption, distribution, metabolism, and excretion (ADME) properties of all newly synthesized pyrazoline compounds(18-25) were predicted using Swissadme online tool. That tool gave information about molecular weight (M.W, Log P o/w c (Octanol-water partition coefficient, Log S (Solubility), log Kp (Skin permeation), hydrogen bond acceptor (Hy- A), number of hydrogen bond donor (Hy- D), Total polar surface area, molar refractivity (M.Ref), bioavailability score. The given parameters help to understand the ADME property of any drugs or organic molecules. One of the molecules developing as an active drug candidate means it should satisfy the Lipinski rule of five and other criteria. Molecular weight $\leq 500$, hydrogen bond acceptor $\leq 10$, hydrogen bond donor $\leq 5, \log \mathrm{P} \leq 5$, molar refractivity $\leq 140$, satisfy the rule of five and then $\log \mathrm{p}$ o/w range between -2 to 6.5 , polar surface area range between 7 to $200, \log \mathrm{S}$ range lie above -4 and the drug score value above 0.5 is accepted one for synthesized compounds. Our synthesized pyrazoline compounds all have above 2.27 up to 7.11 [38].

\subsection{Antimicrobial activity.}

The newly synthesized pyrazoline compounds (18-25) have been evaluated for their antibacterial activity and antifungal activity. Dimethyl sulfoxide is solvent control. These studies were carried out using $1.0 \mathrm{mg} / \mathrm{ml}$ concentrations against four different strains by the agar disk diffusion method.

The antifungal study was also screened for synthesized pyrazoline derivatives (18-25) against Candida albicans strain. This study was carried out using $1.0 \mathrm{mg} / \mathrm{ml}$ concentration by agar disk diffusion method [5].

\subsection{Anti-cancer activity.}

MDA MB 231 Cell line was used to carry out the anti-cancer activity by MTT assay method. The method calculations are followed as such in reference [5].

\section{Results and Discussion}

\subsection{Chemistry.}

1(3-aryl-5-biphenyl-4, 5-dihydropyrazol-1-yl) propan-1-one derivatives (18-25) were synthesized by stirring a mixture of various substituted benzaldehyde (1-8) and 4-acetyl biphenyl (9) in the presence of strong alkali medium. The compound (10-17) was further refluxed with hydrazine hydrate and ethane carboxylic acid for 14-16 $\mathrm{h}$ to synthesize the derivatives (18-25). The reaction mixture was processed by thin-layer chromatography using $\mathrm{CHCl}_{3}$ as a mobile phase. The spots were visualized under the iodine chamber containing iodine vapor. The compounds (18-25) were obtained in good yield, and the ranging between the percentage $68 \%$ to $85 \%$. The target compounds' structures were further elucidated by 
Infrared, ${ }^{1} \mathrm{H}$, and ${ }^{13} \mathrm{C}$ NMR Spectral data were obtained on a Shimadzu 8400 s and Brucker AC $400 \mathrm{MHz}$ spectrometer in $\mathrm{CDCl}_{3}$ and $\mathrm{CHN}$ analysis.

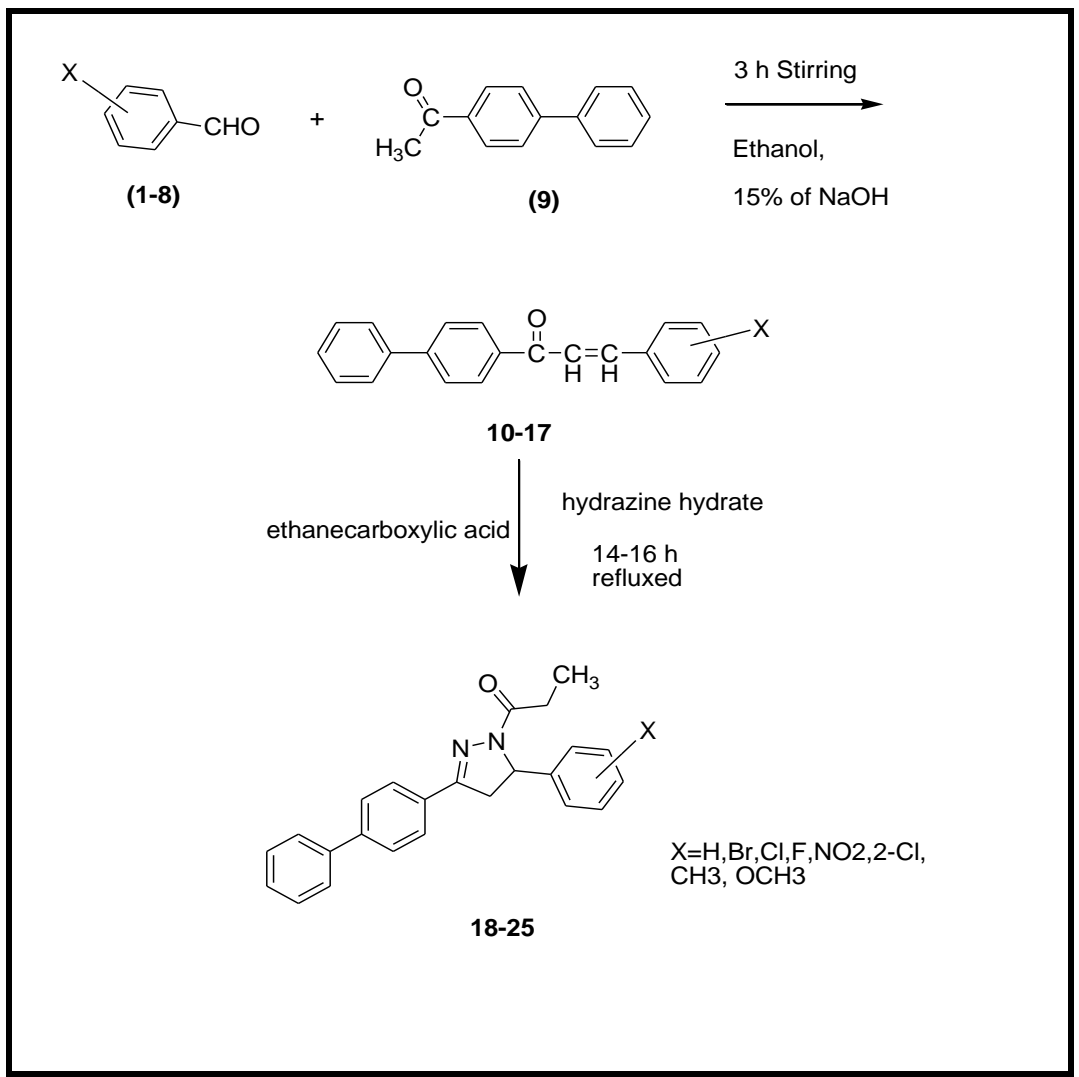

Scheme 1. Synthetic protocol for the compounds (18-25).

\subsubsection{IR, ${ }^{1} \mathrm{H} \&{ }^{13} \mathrm{C}$ NMR spectral analysis.}

The compound 18 exhibit that the sharp absorption at $1579.41 \mathrm{~cm}^{-1}$ is attributed to the $\mathrm{C}=\mathrm{N}$ of pyrazole moiety. The unavailability of the carbonyl absorption band at $1579.41 \mathrm{~cm}^{-1}$ for the presence of $\mathrm{C}=\mathrm{N}$ clearly shows that the formation of in situ acylation in the presence of Propionic acid as solvent. The strong band at $1657.52 \mathrm{~cm}^{-1}$ is unambiguously assigned to amide carbonyl of propanoyl moiety. The strong band at $1405.85 \mathrm{~cm}^{-1}$ is due to $\mathrm{C}-\mathrm{N}$ of pyrazole moiety. The band around at $3072.05 \mathrm{~cm}^{-1}$ is assigned to aromatic $\mathrm{CH}$ stretching. The aromatic ring stretching absorbed at in the range from $534.18 \mathrm{~cm}^{-1}, 692.32 \mathrm{~cm}^{-1}$, and $841.77 \mathrm{~cm}^{-}$ ${ }^{1}$ respectively. Elemental analysis of the compound $\mathbf{1 8}$ (C $\mathrm{C}_{\text {cal }}: 81.32, \mathrm{C}_{\mathrm{obs}}: 81.33$; $\mathrm{H}_{\mathrm{cal}}: 6.20$,

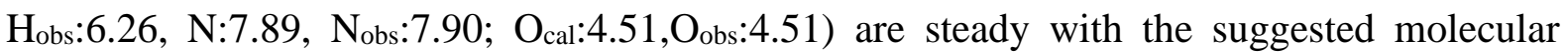
formula $\left(\mathrm{C}_{24} \mathrm{H}_{22} \mathrm{~N}_{2} \mathrm{O}\right)$ of $\mathbf{1 8}$.

The compound 18 shows the $\mathrm{CH}_{2}$ protons $(\mathrm{H}-4 \mathrm{a}$ and $\mathrm{H}-4 \mathrm{e})$ of the pyrazole ring manifest itself as two dd due to multiple coupling involving both germinal and vicinal protons. The signal for $\mathrm{H}-4 \mathrm{a}$ and $\mathrm{H}-4 \mathrm{e}$ are observed at 3.14 and $3.77 \mathrm{ppm}$, respectively. The dd at $3.14 \mathrm{ppm}$ $\mathrm{J}_{4 \mathrm{a}, 4 \mathrm{e}}=4.6 \mathrm{~Hz} \& \mathrm{~J} 4 \mathrm{a}, 5 \mathrm{a}=17.8 \mathrm{~Hz}$ is designate to $\mathrm{H}-4 \mathrm{a}$ proton of pyrazole ring. H-4e proton of pyrazole ring shows the dd at $3.77 \mathrm{ppm} \mathrm{J} 4 \mathrm{e}, 4 \mathrm{a}=12 \mathrm{~Hz} \& \mathrm{~J} 4 \mathrm{e}, 5 \mathrm{a}=17.6 \mathrm{~Hz}$. Likewise, the $\mathrm{CH}$ proton $\mathrm{H}-5 \mathrm{a}$ of pyrazole ring is awaited to give a signal as a doublet of doublet due to vicinal coupling with the two magnetically non-equivalent protons of the $\mathrm{CH}_{2}$ group $(\mathrm{H}-4 \mathrm{a}$ and $\mathrm{H}-4 \mathrm{e}$ )of the pyrazoline ring observed at the dd at $5.54 \mathrm{ppm} \mathrm{J} \mathrm{5a,4a=4.4} \mathrm{Hz} \mathrm{\&} \mathrm{J} \mathrm{5a,} \mathrm{4e}=11.6 \mathrm{~Hz}$. Methyl proton of propanoyl group present at the range 1.18-1.21 ppm (triplet, $\mathrm{CH}_{3}$ ) and a quadrate at 2.80-2.86 ppm signals are indicating the presence of methylene $\left(-\mathrm{CH}_{2}-\right)$ group of the propanoyl 
moiety. Aromatic protons have appeared at the range of $7.11 \mathrm{ppm}$ to $7.81 \mathrm{ppm}$. The ${ }^{13} \mathrm{C}$ spectrum of a compound, 18, shows that the ${ }^{13} \mathrm{C}$ resonance mentioned at $172.42 \mathrm{ppm}$ is attributed to $\mathrm{C}=\mathrm{O}$. The ${ }^{13} \mathrm{C}$ resonance mentioned at $153.26 \mathrm{ppm}$ is due to the $\mathrm{C}-3$ carbon of the pyrazole ring. The ${ }^{13} \mathrm{C}$ resonance noticed at $41.97 \mathrm{ppm}$ is assigned to $\mathrm{C}-4$ carbon of pyrazole ring. The ${ }^{13} \mathrm{C}$ resonance at $59.63 \mathrm{ppm}$ is assigned to the $\mathrm{C}-5$ carbon of the pyrazole ring. The ${ }^{13} \mathrm{C}$ resonance at $27.60 \mathrm{ppm}$ is designate to the ethyl group of the propanoyl ring. The ${ }^{13} \mathrm{C}$ resonance observed at $8.98 \mathrm{ppm}$ is designate to the methyl group of the propanoyl ring. The aromatic carbons have appeared at $121.55-130.20 \mathrm{ppm}$. The remaining ${ }^{13} \mathrm{C}$ signals $(132.05$, $140.10,141.12$, and 143.14) indicate the presence of Ipso carbon. From above the spectral data, we can unambiguously assign the skeleton structure of the compound. The $\mathrm{IR},{ }^{1} \mathrm{H}$, and ${ }^{13} \mathrm{C}$ NMR spectral values shown in Figure 1, Figure 2, and Figure 3.

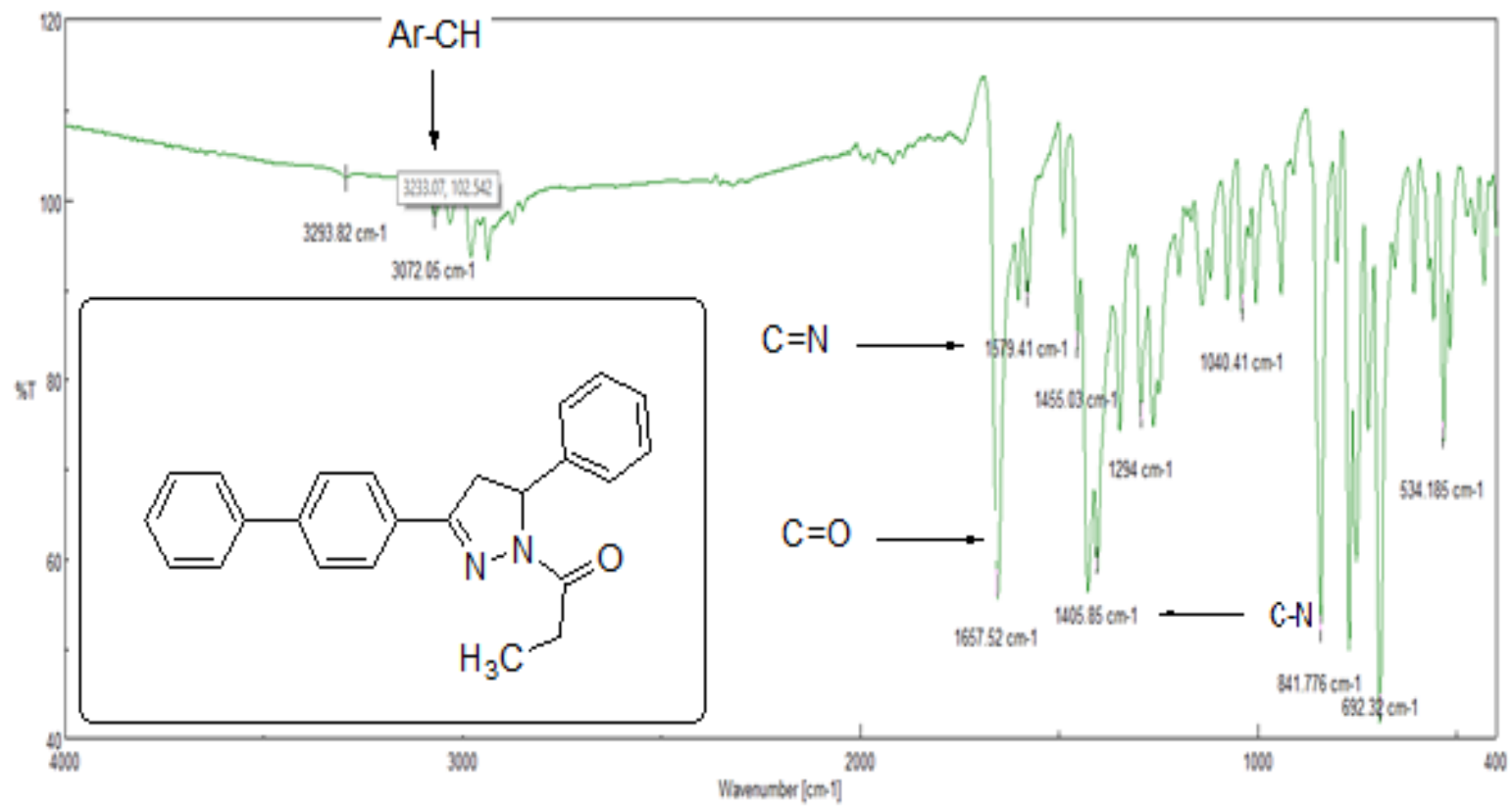

Figure 1. IR spectral data for synthesized compound 18.

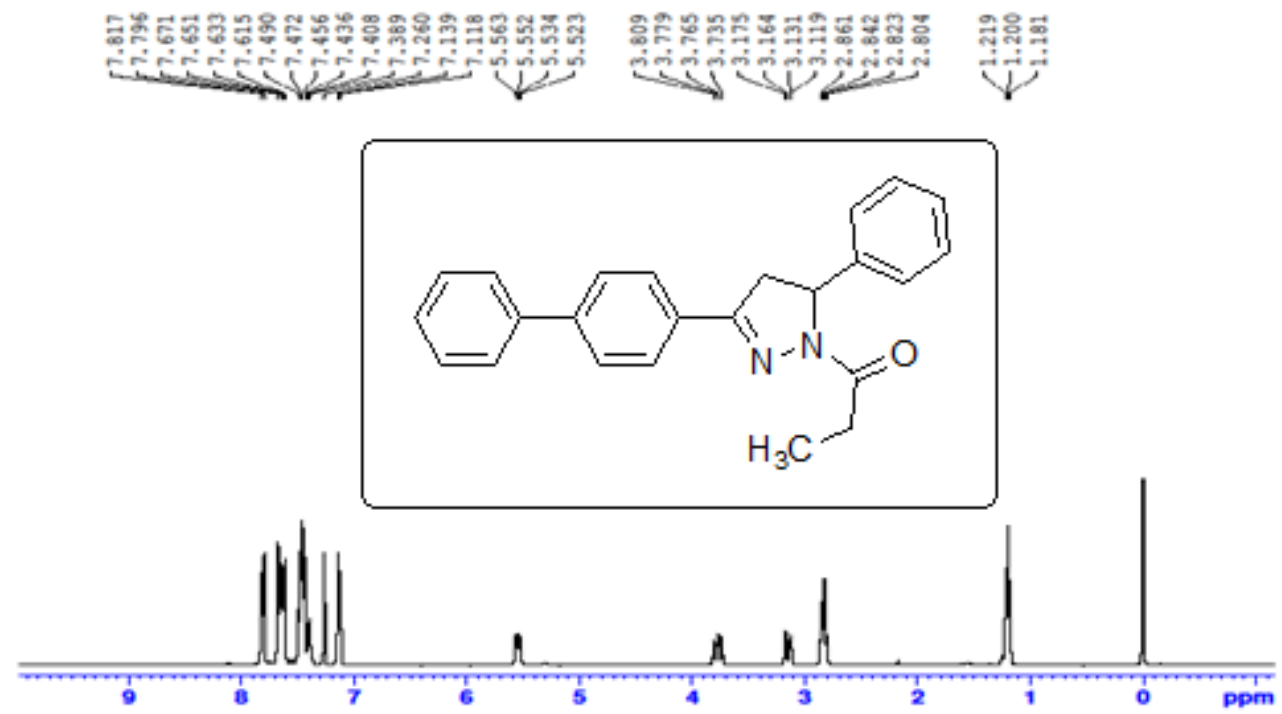

Figure 2. The ${ }^{1} \mathrm{H}$ NMR spectrum for synthesized compound 18. 


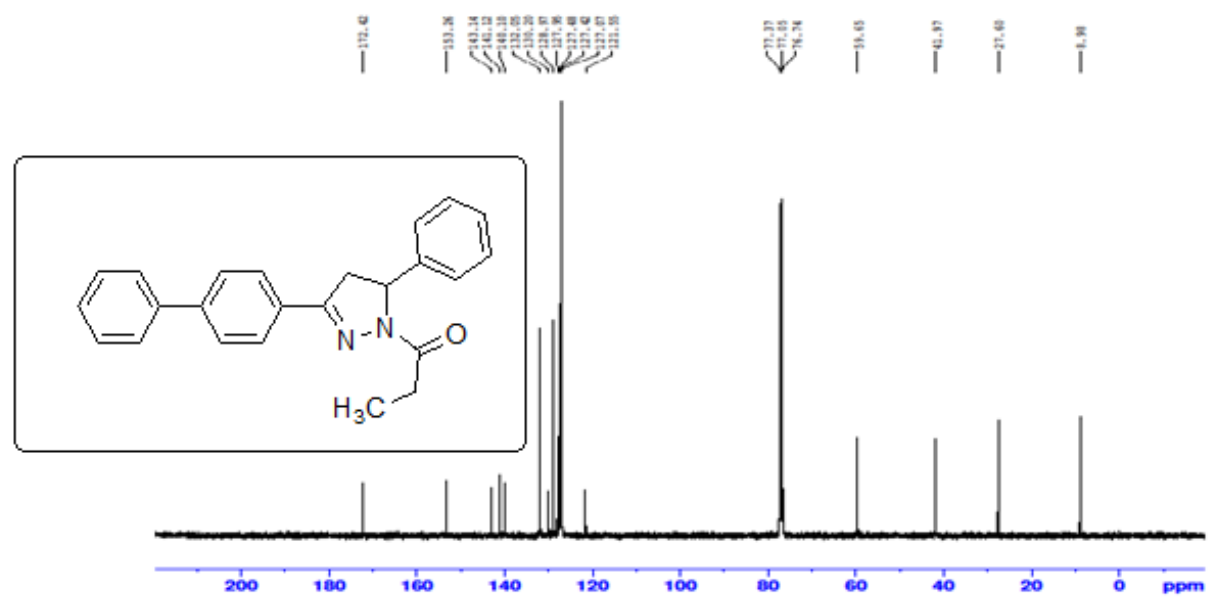

Figure 3. The ${ }^{13} \mathrm{C}$ NMR spectrum for synthesized compound 18 .

\subsection{In-silico studies.}

\subsubsection{Molecular docking.}

To gain an advance apprehend of the potency of the Ligand analog molecule, we proceeded to determine the interaction of synthesized pyrazoline derivatives (18-25) were docked into the catalytic site of receptors $1 \mathrm{UAG}$, The molecular docking studies are given in terms of binding affinity score, and the compounds which have a better interaction had a lower affinity score. In the ligand pyrazoline derivatives (18-25) were docked with bacterial protein, and the experimental docking results are summarized in Table 1. From this table, we come to know the synthesized pyrazoline derivatives (18-25) show better binding contract scores when compared with the standard drug (ciprofloxacin). Among the pyrazoline derivatives (18-25), compounds 19, 20, and 24 exhibited a better binding contract score of $(-8.5 \mathrm{kcal} / \mathrm{mol})$ compared with the standard drug $(-7.7 \mathrm{kcal} / \mathrm{mol})$. Compound 19 and 20 have a conventional hydrogen bond contract LEU A: 299 formed at carbonyl group of the propanoyl moiety; Compound 12 and 24 have a conventional hydrogen bond contract ASN A: 268 formed at carbonyl group of the propanoyl moiety. The 2D and 3D images for compound 19, 20, and 24 are shown in Figure $4,5,6$, respectively. Other compounds binding affinity score, hydrophobic interactions, and conventional hydrogen bond contracts are shown in Table 1.

Table 1. The molecular docking studies for pyrazoline derivatives (18-25) using bacterial protein 1UAG.

\begin{tabular}{l|c|c|c|c} 
Compound & Protein & $\begin{array}{c}\text { Binding affinity } \\
\text { score kcal/mol }\end{array}$ & $\begin{array}{c}\text { Conventional hydrogen } \\
\text { bond interaction }\end{array}$ & $\begin{array}{c}\text { Hydrophobic } \\
\text { interaction }\end{array}$ \\
\hline 18 & 1 UAG & -8.2 & - & $\begin{array}{c}\text { ALA A: 414, LEU } \\
\text { A: } 416\end{array}$ \\
\hline 19 & 1 UAG & -8.5 & LEU A: 299 & - \\
\hline 20 & 1 UAG & -8.5 & LEU A: 299 & - \\
\hline 21 & 1 UAG & -8.4 & ASN A: 268 & - \\
\hline 22 & 1 UAG & -8.2 & GLN A: 266, HIS A: 267 & $\begin{array}{c}\text { LEU A: } 216, \text { ALA } \\
\text { A: 328 }\end{array}$ \\
\hline 23 & 1 UAG & -8.2 & ASN A: 178, ASN A: 211 & ALA A: 328 \\
\hline 24 & 1 UAG & -8.5 & ASN A: 268 & - \\
\hline 25 & 1 UAG & -8.4 & LEU A: 299 & - \\
\hline Ciprofloxacin & 1 UAG & -7.7 & ASN A: 178, ASN A: & ALA A: 328
\end{tabular}




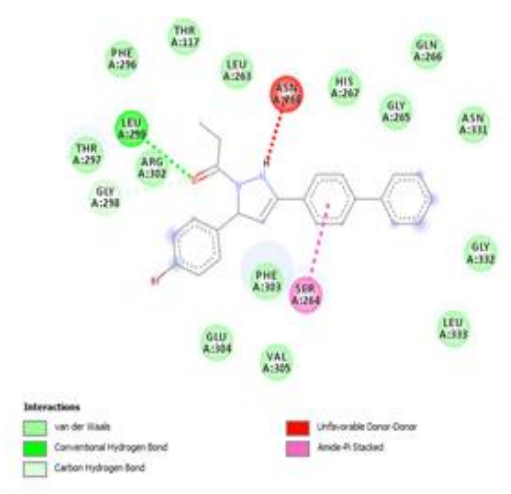

2D image

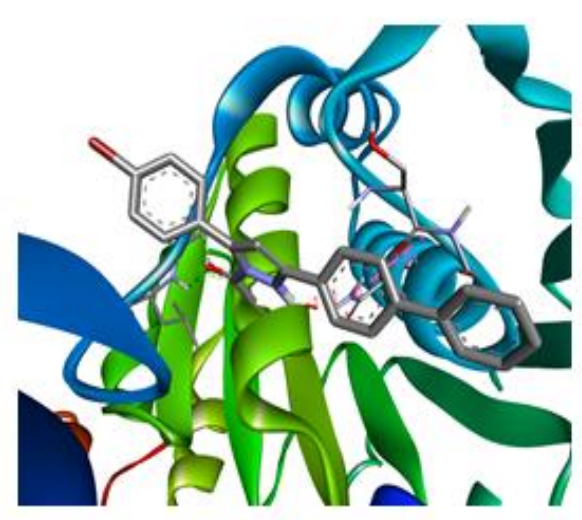

3D image

Figure 4. Compound 19 docked with $1 \mathrm{UAG}$ protein.

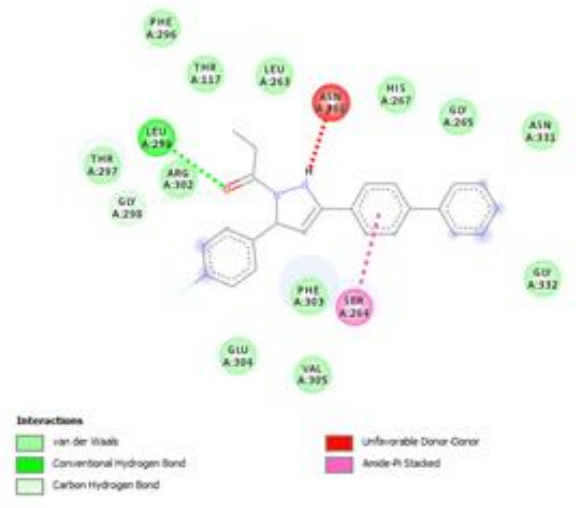

2D image

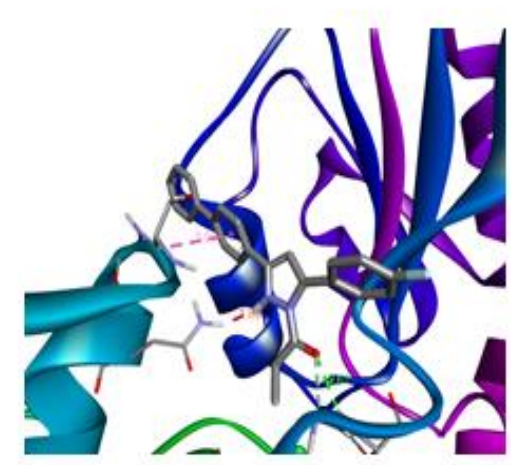

3D image

Figure 5. Compound 20 docked with 1 UAG protein.

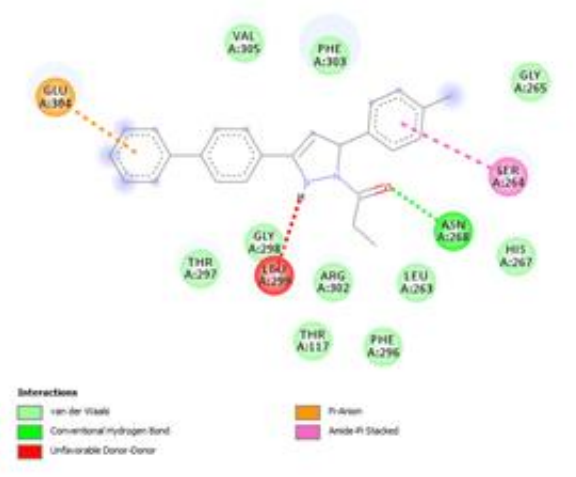

2D image

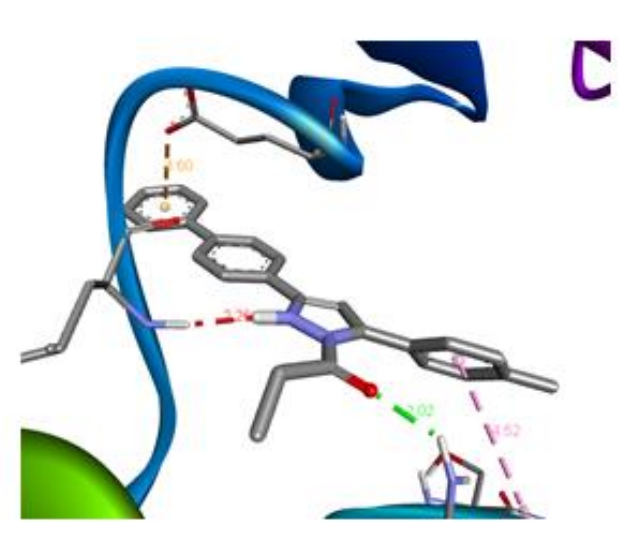

3D image

Figure 6. Compound 24 docked with the protein 1UAG.

3.2.2. Docking studies carried out using breast cancer protein.

The compounds (18-25) were carried for docking by breast cancer protein 1OQA. The experimental results are given in Table 2. All the synthesized compounds have good binding https://biointerfaceresearch.com/ 
affinity score, especially the compound 21 exhibited a better binding affinity score -7.7 $\mathrm{kcal} / \mathrm{mol}$. According to better binding contract score compound, 21 have no conventional hydrogen bond interaction with the selected protein, but this compound has two hydrophobic interactions CYS A: 15 and VAL A: 38. The 2D and 3D images for compound 21, shown in Figure 7.

Table 2. The molecular docking studies for compounds (18-25) using 1OQA.

\begin{tabular}{l|c|c|c|c} 
Compound & Protein Name & $\begin{array}{c}\text { Binding contract } \\
\text { score kcal/mol }\end{array}$ & Hydrogen bond & $\begin{array}{c}\text { Hydrophobic } \\
\text { interaction }\end{array}$ \\
\hline 18 & 1OQA & -7.6 & GLN A: 104 & $\begin{array}{c}\text { PRO A: 59, ILE } \\
\text { A: } 102\end{array}$ \\
\hline 19 & 1OQA & -7.3 & - & $\begin{array}{c}\text { CYS A: } 15, \text { PRO } \\
\text { A: } 18, \text { VAL A: } 38\end{array}$ \\
\hline 20 & 1OQA & -7.5 & GLN A: 104 & PRO A: 59 \\
\hline 21 & 1OQA & -7.7 & - & $\begin{array}{c}\text { CYS A: } 15, \text { VAL } \\
\text { A: } 38\end{array}$ \\
\hline 22 & 1OQA & -7.6 & - & $\begin{array}{c}\text { PRO A: } 18, \text { CYS } \\
\text { A: } 15\end{array}$ \\
\hline 23 & & & & PRO A: 59 \\
\hline 24 & 1OQA & -7.6 & GLN A: 104 & PRO A: 59 \\
\hline 25 & 1OQA & -7.4 & GLN A: 104 & PRO A: 59, ILE \\
& 1OQA & -7.6 & GLN A: 104 &
\end{tabular}

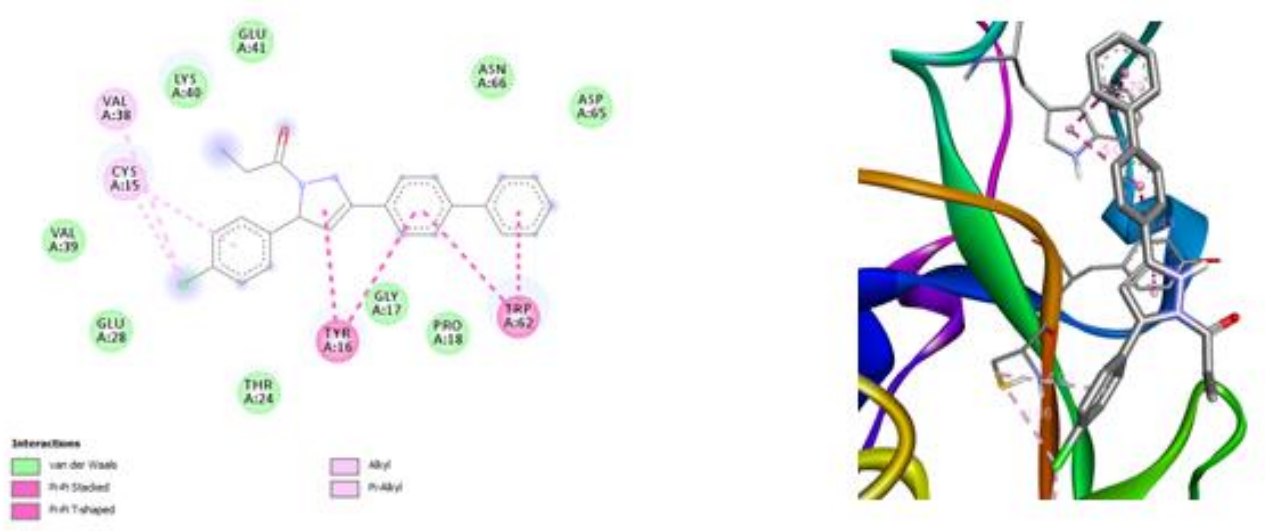

Figure 7. 2D and 3D images for compound 21.

\subsubsection{ADME property.}

The synthesized pyrazoline compound (18-25) subjected to in-silico ADME property prediction with the help of Swiss-ADME online software http://www.swissadme.ch [41]. Adsorption (\% ABS ) of compounds from intestinal was figured out by: \% ABS $=109-(0.345$ x Topological Polar Surface Area (TSPA))[42].Swiss ADME property gives a physiochemical property of feasible oral drug candidates according to five different rules determined by the Lipinski's, Ghose, Veber, Egan, and Muegge [41-45]. Our synthesized compounds have a bearable pharmacokinetics profile. Quantitative class of solubility in water is defined as insoluble $<-10<$ poorly soluble $<-6<$ moderately soluble $<-4<$ soluble $<-2<$ very $<0<$ highly. As states to the results, all the compounds have moderately soluble in water. From the ADME prediction results, the compound (18-25) should obey the Lipinski rule of five with 0 and 1 violation, and they also have high TPSA values of 72.98, 41.90, good drug-likeness values of 5.21, 5.58 other these two compounds also obey the Veber rule because it has a 
number of rotational bonds $\leq 10$. The compound 21 has a high drug-likeness score of 7.11 then the other compounds in the series. The compound 22 and 25 have other good values in the log $S$ value less than -6.5 . The results of the prediction of ADME properties are depicted in Table 3. The synthesized compounds (18-25) possess better drug-likeness, and drug score values $[46,47]$.

Table 3. Absorption, Distribution, Metabolism, and Excretion results of synthesized pyrazoline compound (1825) by swiss ADME.

\begin{tabular}{l|c|c|c|c|c|c|c|c|c|c} 
Compound & $\mathbf{M W}$ & $\begin{array}{c}\boldsymbol{\%} \\
\mathbf{A B S}\end{array}$ & $\begin{array}{c}\mathbf{L o g} \\
\mathbf{P}_{\mathbf{0} / \mathbf{w}} \mathbf{c}\end{array}$ & $\mathbf{n - O H}$ & $\begin{array}{c}\mathbf{n}- \\
\mathbf{O H N H}\end{array}$ & $\mathbf{M} \mathbf{R f y}$ & $\begin{array}{c}\mathbf{n}- \\
\text { violation }\end{array}$ & $\begin{array}{c}\text { Log } \\
\text { S(ESOL) }\end{array}$ & $\begin{array}{c}\text { TPSA } \\
\text { in } \mathbf{\AA}\end{array}$ & $\begin{array}{c}\text { Drug } \\
\text { likeness }\end{array}$ \\
\hline 18 & 354.44 & 97.73 & 4.52 & 2 & 0 & 117.27 & 1 & -5.22 & 32.67 & 3.19 \\
\hline 19 & 433.34 & 97.73 & 5.15 & 2 & 0 & 124.97 & 1 & -6.13 & 32.67 & 1.13 \\
\hline 20 & 388.89 & 97.73 & 5.07 & 2 & 0 & 122.28 & 1 & -5.82 & 32.67 & 2.60 \\
\hline 21 & 372.43 & 97.73 & 4.84 & 3 & 0 & 117.23 & 1 & -5.38 & 32.67 & 7.11 \\
\hline 22 & 399.44 & 81.93 & 3.92 & 4 & 0 & 126.10 & 0 & -5.28 & 78.49 & 5.21 \\
\hline 23 & 388.89 & 97.73 & 5.04 & 2 & 0 & 122.28 & 1 & -5.82 & 32.67 & 5.89 \\
\hline 24 & 368.47 & 97.73 & 4.85 & 2 & 0 & 122.24 & 1 & -5.52 & 32.67 & 4.14 \\
\hline 25 & 384.47 & 94.55 & 4.51 & 3 & 0 & 123.77 & 0 & -5.29 & 41.90 & 5.58
\end{tabular}

$\mathrm{M} . \mathrm{W}=$ Molecular weight, $\mathrm{n}-\mathrm{OH}=$ number of hydrogen bond acceptor, $\mathrm{n}-\mathrm{OHNH}=$ number of hydrogen bond donor, M.Rfy = Molar Refractivity, TPSA = Total Polar Surface Area,Log S=Solubility

3.2.4. Pharmacokinetics and drug likeness.

The pharmacokinetic properties and drug-likeness predictions were carried for the free online ADME toolkit like swissadme and molinspiration, respectively; the data were given Tables 4 and 5. According to these properties, all the compounds showed a high gastrointestinal (GI) absorption. All the compounds have Blood-Brain Barrier permeability except compound 22. Nevertheless, most of the compounds showed inhibition to Cytochrome P450 isomers (CYP1A2, CYP2C19, CYP2C9, CYP2D6, and CYP3A4)[48]. The drug-likeness prediction was carried depending on the selected rules like Lipinski's, Ghose, and Veber and bioavailability scores. According to Lipinski's rule, the absorption or permeation of a more is more likely when the molecular weight is under $500 \mathrm{~g} / \mathrm{mol}$, the value of $\log \mathrm{P}$ is lower than 5 , and the molecule has the utmost $5 \mathrm{H}$-donor and $10 \mathrm{H}$-acceptor. Ghose filter defines druglikeness restriction as follows: calculated $\log \mathrm{P}$ value is obtained between 3.92 and 5.57, mw is obtained between 354 and 433, molar refractivity is between 117 and 127, and the total number of an atom is between 27 and 30 . Veber rule states that drug-likeness constrains as Rotatable bond count $\leq 10$ and polar surface area (PSA) $\leq 140$. All the compounds have a similar bioavailability score of 0.55 . Screening process with Lipinski's rule of five states that most of the compounds meet the criteria of drug-likeness assessments. According to the screening process with Ghose rules showed that all the synthesized compounds were meet the criteria. The compound has one violation, i.e., WLOGP> 5.6. However, the screening process with Veber rules, all the compounds have met the criteria of drug-likeness assessment. The medicinal property also carried by Molinspiration software. From the study Pains and Brenk are the two filters, these two filters have no alerts in all the synthesized compounds. All the compounds have the synthetic ability value between 3.50 and 3.82. From these values of synthetic ability, the synthesized compounds obeyed the medicinal chemistry property. The values are given in Table 4. The drug-likeness model score (a combined effect of physical, chemical properties, pharmacokinetics, and pharmacodynamics of a compound and is displayed by numerical value) was calculated by Molinspiration software(http://www.molinspiration.com) for the eight synthesized compounds. The best druglikeness score was found to be -0.41 for the compounds 19 and 21, respectively (see Figure 8). 
Table 4. Pharmacokinetics, Druglikeness, and Medicinal chemistry of synthesized compounds (18-25).

\begin{tabular}{|c|c|c|c|c|c|c|c|c|}
\hline Compound & 18 & 19 & 20 & 21 & 22 & 23 & 24 & 25 \\
\hline \multicolumn{9}{|c|}{ Pharmacokinetics } \\
\hline GI absorption & High & High & High & High & High & High & High & High \\
\hline BBB permeant & Yes & Yes & Yes & Yes & No & Yes & Yes & Yes \\
\hline P-gp & No & No & No & No & No & No & No & No \\
\hline CYP1A2 & No & No & No & $\mathrm{No}$ & $\mathrm{No}$ & No & $\mathrm{No}$ & No \\
\hline CYP2C19 & Yes & Yes & Yes & Yes & Yes & Yes & Yes & Yes \\
\hline CYP2C9 & Yes & Yes & Yes & Yes & Yes & Yes & Yes & Yes \\
\hline CYP2D6 & No & $\mathrm{No}$ & No & $\mathrm{No}$ & No & No & No & $\mathrm{No}$ \\
\hline CYP3A4 & Yes & Yes & Yes & Yes & Yes & Yes & Yes & Yes \\
\hline $\begin{array}{l}\text { Log } \mathrm{K}_{\mathrm{p}}(\mathrm{skin} \\
\text { permeation) } \mathrm{cm} / \mathrm{s}\end{array}$ & -5.05 & -5.05 & -4.82 & -5.09 & -5.45 & -4.82 & -4.88 & -5.26 \\
\hline \multicolumn{9}{|c|}{ Drug Likeness } \\
\hline Lipinski & $\begin{array}{c}\text { Yes; } 1 \\
\text { violation }\end{array}$ & $\begin{array}{c}\text { Yes; } 1 \\
\text { violation }\end{array}$ & $\begin{array}{c}\text { Yes; } 1 \\
\text { violation }\end{array}$ & $\begin{array}{c}\text { Yes; } 1 \\
\text { violation }\end{array}$ & $\begin{array}{c}\text { Yes; } 0 \\
\text { violation }\end{array}$ & $\begin{array}{c}\text { Yes; } 1 \\
\text { violation }\end{array}$ & $\begin{array}{c}\text { Yes; } 1 \\
\text { violation }\end{array}$ & $\begin{array}{c}\text { Yes;0 } \\
\text { violation }\end{array}$ \\
\hline Ghose & Yes & Yes & Yes & Yes & Yes & Yes & Yes & Yes \\
\hline Veber & Yes & Yes & Yes & Yes & Yes & Yes & Yes & Yes \\
\hline Egan & Yes & Yes & Yes & Yes & Yes & Yes & Yes & Yes \\
\hline Muegge & Yes & $\begin{array}{c}\text { No;1 } \\
\text { violation }\end{array}$ & $\begin{array}{c}\text { No;1 } \\
\text { violation }\end{array}$ & Yes & Yes & $\begin{array}{c}\text { No; } 1 \\
\text { violation }\end{array}$ & $\begin{array}{c}\text { No; } 1 \\
\text { violation }\end{array}$ & yes \\
\hline $\begin{array}{l}\text { Bioavailability } \\
\text { score }\end{array}$ & 0.55 & 0.55 & 0.55 & 0.55 & 0.55 & 0.55 & 0.55 & 0.55 \\
\hline \multicolumn{9}{|c|}{ Medicinal Chemistry } \\
\hline PAINS & 0 alert & 0 alert & 0 alert & 0 alert & 0 alert & 0 alert & 0 alert & 0 alert \\
\hline Brenk & 0 alert & 0 alert & 0 alert & 0 alert & $\begin{array}{c}1 \text { alert } \\
\mathrm{NO}_{2} \text { gp }\end{array}$ & 0 alert & 0 alert & 0 alert \\
\hline Leadlikeness & $\begin{array}{c}\text { No; } 2 \\
\text { violation }\end{array}$ & $\begin{array}{c}\text { No; } 2 \\
\text { violation }\end{array}$ & $\begin{array}{c}\text { No; } 2 \\
\text { violation }\end{array}$ & $\begin{array}{c}\text { No; } 2 \\
\text { violation }\end{array}$ & $\begin{array}{c}\text { No; } 2 \\
\text { violation }\end{array}$ & $\begin{array}{c}\text { No; } 2 \\
\text { violation }\end{array}$ & $\begin{array}{c}\text { No; } 2 \\
\text { violation }\end{array}$ & $\begin{array}{c}\text { No; } 2 \\
\text { violation }\end{array}$ \\
\hline $\begin{array}{l}\text { Synthetic } \\
\text { accessbility }\end{array}$ & 3.70 & 3.50 & 3.72 & 3.73 & 3.76 & 3.81 & 3.82 & 3.77 \\
\hline
\end{tabular}

GI absorption: Gastrointestinal absorption, BBB permeant: Blood-Brain Barrier permeant, P-gp: glycoprotein, CYP: Cytochrome P450 isomer

Table 5. Pharmacokinetic parameters are important for good oral bioavailability of synthesized compounds (1825).

\begin{tabular}{|c|c|c|c|c|c|c|c|c|c|}
\hline $\begin{array}{l}\text { Compound } \\
\text { Code }\end{array}$ & miLogp & TPSA & n-atoms & MW & n-OH & $\begin{array}{c}\text { n- } \\
\text { OHNH }\end{array}$ & $\begin{array}{c}\mathbf{n}- \\
\text { violation }\end{array}$ & n-rot.b & volume \\
\hline 18 & 5.56 & 32.67 & 27 & 354.45 & 3 & 0 & 1 & 4 & 338.04 \\
\hline 19 & 6.37 & 32.67 & 28 & 433.35 & 3 & 0 & 1 & 4 & 355.92 \\
\hline 21 & 5.72 & 32.67 & 28 & 372.44 & 3 & 0 & 1 & 4 & 342.97 \\
\hline 22 & 5.52 & 78.50 & 30 & 399.45 & 6 & 0 & 1 & 5 & 361.37 \\
\hline 23 & 6.91 & 32.67 & 28 & 388.90 & 3 & 0 & 1 & 4 & 351.57 \\
\hline 25 & 5.61 & 41.91 & 29 & 384.48 & 4 & 0 & 1 & 5 & 363.58 \\
\hline
\end{tabular}

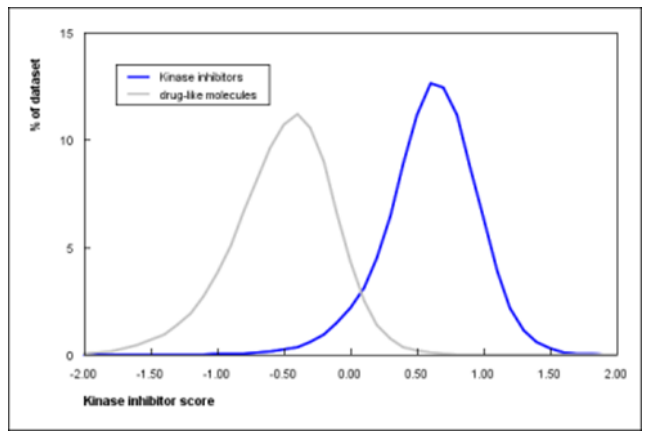

Figure 8. Drug-likeness model score of compound 21.

\subsubsection{Bioactivity score.}

The results showed that some of the synthesized compounds have physiochemical properties within the acceptable range. By using molinspiration software online test, the 
bioactivity of all compounds was predicted and represented in Table 6. The bioactivity score of the synthesized compounds indicated the probability of good to moderate activity towards GCPR ligands, Ion channel modulators, Kinase inhibitor, Nuclear receptor Ligand, Protease inhibitor, and other enzyme inhibitors. These score for organic molecules can be interpreted as active (bioactivity> 0), moderately active (bioactive score: -5.0- 0.0) and inactive (bioactivity score $<-5.0)[49]$.

Table 6.Bioactivity score of synthesized compounds (18-25).

\begin{tabular}{l|c|c|c|c|c|c}
$\begin{array}{l}\text { Compound } \\
\text { Code }\end{array}$ & $\begin{array}{c}\text { G-Protein } \\
\text { Coupled } \\
\text { Receptor ligand }\end{array}$ & $\begin{array}{c}\text { Ion channel } \\
\text { modulator }\end{array}$ & $\begin{array}{c}\text { Kinase } \\
\text { Inhibitor }\end{array}$ & $\begin{array}{c}\text { Nuclear } \\
\text { receptor } \\
\text { ligand }\end{array}$ & $\begin{array}{c}\text { Protease } \\
\text { inhibitor }\end{array}$ & $\begin{array}{c}\text { Enzyme } \\
\text { inhibitor }\end{array}$ \\
\hline 18 & -0.26 & -0.77 & -0.45 & -0.45 & -0.33 \\
\hline 19 & -0.34 & -0.81 & -0.41 & -0.54 & -0.42 & -0.31 \\
\hline 20 & -0.25 & -0.75 & -0.45 & -0.46 & -0.35 & -0.32 \\
\hline 21 & -0.24 & -0.76 & -0.41 & -0.42 & -0.34 & -0.32 \\
\hline 22 & -0.36 & -0.74 & -0.53 & -0.50 & -0.42 & -0.38 \\
\hline 23 & -0.27 & -0.78 & -0.54 & -0.43 & -0.43 & -0.37 \\
\hline 24 & -0.28 & -0.81 & -0.47 & -0.47 & -0.37 & -0.35 \\
\hline 25 & -0.28 & -0.78 & -0.45 & -0.43 & -0.36 & -0.33 \\
\hline Std-1 & 0.12 & -0.04 & -0.07 & -0.19 & -2.0 & -0.28 \\
\hline Std-2 & 0.17 & 0.30 & 0.14 & -0.21 & -0.13 & 0.42
\end{tabular}

Standard-1: ciprofloxacin, Standard-2:Clotrimazole

3.2.6. MTT assay for compound 21.

According to the best binding affinity score, compound $\mathbf{2 1}$ is performed in-vitro anticancer activity against MDA-MB-231 Cell line by MTT assay method. In-vitro anticancer activity was done using various concentrations (100, 50, 25, 12.5, and $6.25 \mu \mathrm{g} / \mathrm{ml})$. Except for the dilution $6.25 \mu \mathrm{g} / \mathrm{ml}$ of concentration, compound 21 gave us a good activity in all the concentrations. Because at low concentration, compound 21, which has an electronegativity group(4-Chloro) attached in the fourth position of the phenyl ring, showed good activity. The LC50 value of compound $\mathbf{2 1}$ is $92.31 \mu \mathrm{g} / \mathrm{ml}$. These procedures were conducted in triplicate (see Figure 9).

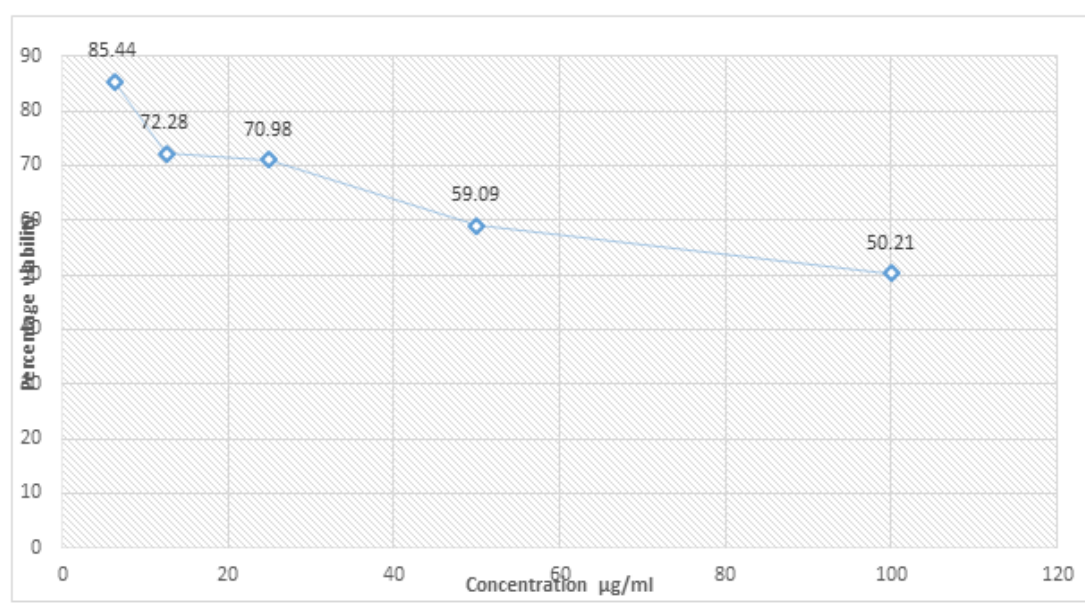

Figure 9. In-vitro anti-cancer activity screening for compound 21 at low concentration.

\subsubsection{Biology.}

The compounds (18-25) were performed for antimicrobial studies using various bacterial strains. They are $S$. aureus, St. pyogenes, E. coli, and P. aeruginosa. In this study, we 
are using $1.0 \mathrm{mg} / \mathrm{ml}$ concentration. From this result, synthesized pyrazoline compounds (1825) exhibit a good zone of inhibition when compared with the standard drug (ciprofloxacin). Especially, compound 21 exhibit an excellent zone of inhibition compared with ciprofloxacin. From this outcome, compound $\mathbf{2 1}$ has an electronegativity group (4-Cl) that is directly attached to the benzene ring of the pyrazoline compound. For that reason, this compound exhibit excellent activity among the series of eight compounds (18-25).

Table 7. Antimicrobial activity results of synthesized pyrazoline compounds (18-25).

\begin{tabular}{l|c|c|c|c|c}
\multirow{2}{*}{$\begin{array}{c}\text { Compound } \\
\text { Code }\end{array}$} & \multicolumn{4}{|c|}{ Bacterial Strain } & Fungal Strain \\
\cline { 2 - 6 } & S. aureus & E. coli & St. pyogenes & P. aeruginosa & C. albicans \\
\hline 18 & 17 & 15 & 11 & 19 & 12 \\
\hline 19 & 21 & 18 & 17 & 13 & 11 \\
\hline 20 & 19 & 13 & 17 & 12 & 13 \\
\hline 21 & 26 & 21 & 16 & 23 & 19 \\
\hline 22 & 21 & 15 & 18 & 14 & 13 \\
\hline 23 & 16 & 14 & 17 & 19 & 10 \\
\hline 24 & 20 & 19 & 18 & 20 & 11 \\
\hline 25 & 19 & 11 & 15 & 12 & 18 \\
\hline $\begin{array}{l}\text { Ciprofloxacin/ } \\
\text { Clotrimazole }\end{array}$ & $\mathbf{2 6}$ & $\mathbf{1 9}$ & $\mathbf{1 7}$ & $\mathbf{2 2}$ & $\mathbf{2 4}$
\end{tabular}

The antifungal activity was screened for synthesized pyrazoline derivatives (18-25) using $1.0 \mathrm{mg} / \mathrm{ml}$ concentration by agar disk diffusion method against Candida albicans strain. The experimental reports are given in Table 7. From this result, it is understood that synthesized pyrazoline compounds $\mathbf{2 1}$ and $\mathbf{2 5}$ exhibits a good zone of inhibition compared with a standard drug (clotrimazole) (see Figure 10).

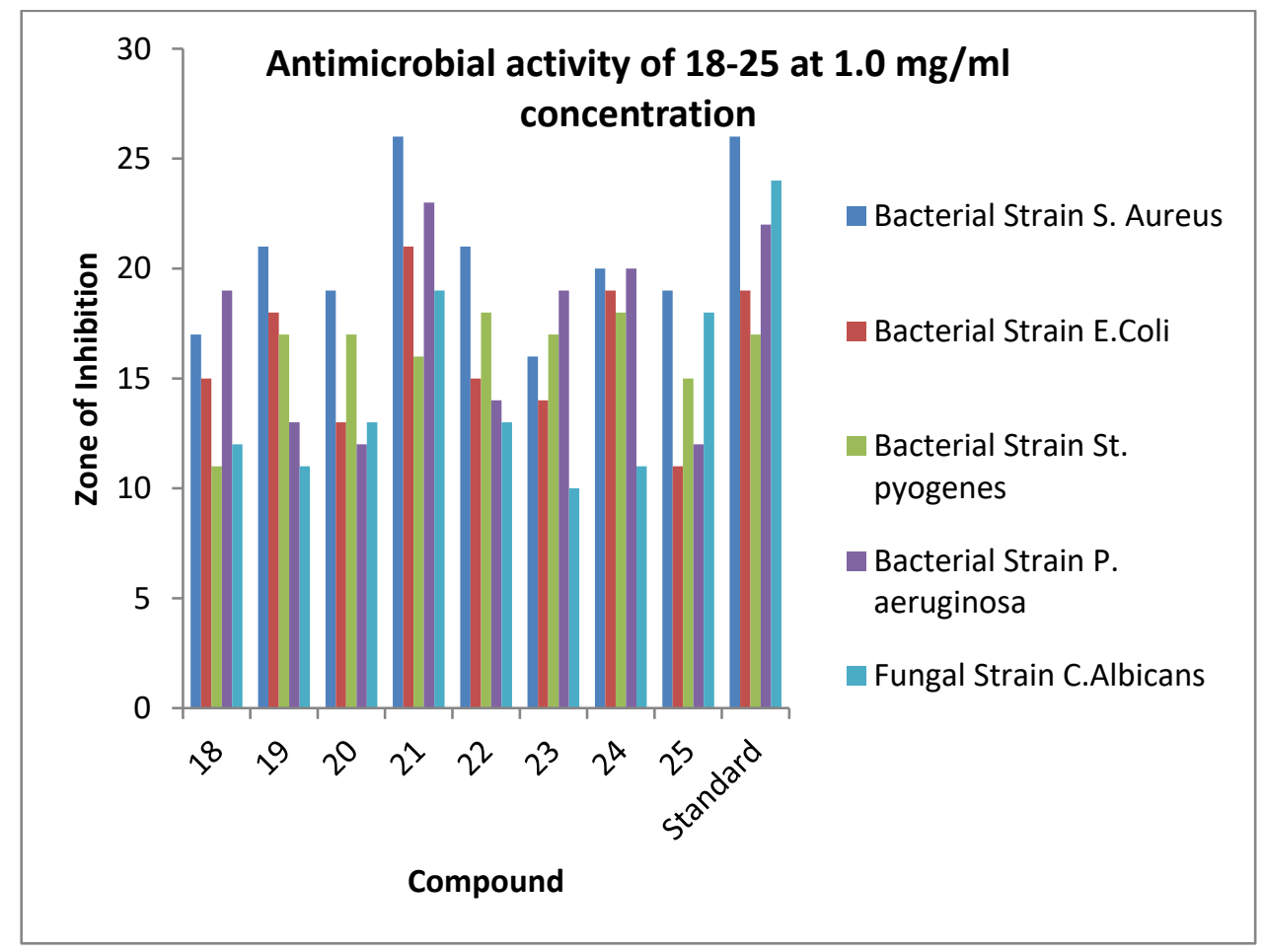

Figure 10. In-vitro studies of synthesized pyrazoline compounds (18-25) graphical representation.

\section{Conclusions}

A new series of pyrazoline analogs (18-25) compounds were synthesized by the cyclization method. The skeleton of the compound structure was characterized using IR, ${ }^{1} \mathrm{H}-$ NMR, and ${ }^{13} \mathrm{C}-\mathrm{NMR}$ spectral studies. Synthesized pyrazoline derivatives (18-26) were 
subjected to molecular docking studies using bacterial protein 1UAG. From this docking result, it is found pyrazoline derivatives (18-25) show a moderate to better binding affinity score when compared with the standard drug (ciprofloxacin). Especially compound 19, 20, and 24 are shown high binding affinity score among the ten pyrazoline compounds (18-25) and standard drug. Furthermore, synthesized pyrazoline derivatives (18-25) docked with breast cancer protein. From the study, compound 21 shows a better binding affinity score among the ten pyrazoline compounds (18-25). According to the better result in the docking, the compound 21 was performed to in-vitro anti-cancer activity (human breast adenocarcinomaMDA-MB-231 Cell line) by MTT assay, compound 21 exhibits a good activity at low concentration and the LC50 value is $92.31 \mu \mathrm{g} / \mathrm{ml}$. The pyrazoline derivatives were also screened for antimicrobial activity. From this result, synthesized pyrazoline compounds 21 and 25 excellent exhibit activities compared with ciprofloxacin and clotrimazole. The in-silico ADME property was carried out to this pyrazoline compounds (18-25). From this result of ADME property, it is established that our synthesized pyrazoline compounds have a good drug-likeness score.

\section{Funding}

This research received no external funding.

\section{Acknowledgments}

We thank the Biogenic Research Centre for recording the MDA MB cell line anti-cancer activity.

\section{Conflicts of Interest}

The authors declare no conflict of interest.

\section{References}

1. Siegel, R.L.; Miller, K.D; Jemal, A. Cancer Statistics. Cancer Journal for Clinicians.2017, 67, 7-30, https://doi.org/10.3322/caac.21387.

2. Wiren, S.; Haggstrom, C.; Ulmer H.;et al. Pooled cohort study on height and risk of cancer and cancer death. Cancer Causes Control. 2014, 25,151-159 doi: 10.1007/s10552-013-0317-7

3. Arruebo, M.; Vilaboa, N.; Sáez-Gutierrez, B.; Lambea, J.; Tres, A.; Valladares, M.; González-Fernández, Á. Assessment of the Evolution of Cancer Treatment Therapies. Cancers 2011, 3, 32793330,https://doi.org/10.3390/cancers3033279.

4. Aydemir, N.; Bilaloğlu, R. Genotoxicity of two anti-cancer drugs, gemcitabine and topotecan, in mouse bone marrow in vivo. Mutation research 2003, 537, 43-51, https://doi.org/10.1016/s1383-5718(03)00049-4.

5. Raja, C.; Ezhilarasi, M.R.; Prabha, B.; Kulandhaivel, M. Synthesis and characterization of cyclohexane-1,3dione derivatives, and their in-silico and in-vitro studies on antimicrobial and breast cancer activity. Asian J. Pharm and Clinical Research2019, 12, 311-320,http://dx.doi.org/10.22159/ajpcr.2019.V12i3.30481.

6. Rathinamanivannan, S.; Megha, K.; Chinnamanayakar, R.; Kumar, A.; M.R.E. Synthesis and Characterization of 2-Pyrazoline Derivatives and their in silico and in vitro Studies on Antimicrobial and Anticancer Activities. Asian Journal of Chemistry 2019, 31, 2191-2196, https://doi.org/10.14233/ajchem.2019.22082.

7. Boström, J.; Hogner, A.; Llinàs, A.; Wellner, E.; Plowright, A.T. Oxadiazoles in Medicinal Chemistry. Journal of Medicinal Chemistry 2012, 55, 1817-1830,https://doi.org/10.1021/jm2013248.

8. Khumar, A.B.; Ezhilarasi, M.R; Prabha, B. Molecular Docking Study of Novel Synthesized Pyrazole Derivatives and their Antibacterial Activity. Asian Journal of Chemistry 2018, 30, 741746,https://doi.org/10.14233/ajchem.2018.20913.

9. Ali, I.; Mukhtar, S.D.; Hsieh, M.F.; Alothman, Z.A.; Alwarthan, A. Facile synthesis of indole heterocyclic compounds based micellar nano anti-cancer drugs. RSC Advances 2018, 8, 3790537914,http://doi.org/10.1039/c8ra07060a. 
10. Nosik, P.S.; Poturai, A.S.; Pashko, M.O.; Melnykov, K.P.; Ryabukhin, S.V.; Volochnyuk, D.M.; Grygorenko, O.O. N-Difluorocyclopropyl-Substituted Pyrazoles: Synthesis and Reactivity. European Journal of Organic Chemistry 2019, 2019, 4311-4319,https://dx.doi.org/10.1002/ejoc.201900123.

11. Mehlika Dilek, A.; Ahmet, O.; Sinem, I.; Ozlem, A. Synthesis and Biological Evaluation of New Pyrazolebased Thiazolyl Hydrazone Derivatives as Potential Anti-cancer Agents. Letters in Drug Design \& Discovery 2014, 11, 833-839, https://doi.org/10.2174/1570180811666140226235350.

12. Surendra Kumar, R.; Arif, I.A.; Ahamed, A.; Idhayadhulla, A. Anti-inflammatory and antimicrobial activities of novel pyrazole analogues. Saudi Journal of Biological Sciences 2016, 23, 614-620, https://doi.org/10.1016/j.sjbs.2015.07.005.

13. Ashish, K.T.; Anil, M.; Verma, H.N.; Mishra, A. Synthesis and antiviral activities of N-substituted-2substituted benzimidazole derivatives. Indian J of Chemistry2006,45B, 489-492.

14. Ningaiah, S.; Bhadraiah, U.K.; Doddaramappa, S.D.; Keshavamurthy, S.; Javarasetty, C. Novel pyrazole integrated 1,3,4-oxadiazoles: Synthesis, characterization and antimicrobial evaluation. Bioorg Med Chem Lett 2014, 24, 245-248,https://doi.org/10.1016/j.bmcl.2013.11.029.

15. Viveka, S.; Dinesha; Madhu, L.N.; Nagaraja, G.K. Synthesis of new pyrazole derivatives via multicomponent reaction and evaluation of their antimicrobial and antioxidant activities. Monatshefte für Chemie - Chemical Monthly 2015, 146, 1547-1555, https://doi.org/10.1007/s00706-015-1428-5.

16. Çetin, A.; Bildirici, İ. A study on synthesis and antimicrobial activity of 4-acyl-pyrazoles. Journal of Saudi Chemical Society 2018, 22, 279-296, https://doi.org/10.1016/j.jscs.2016.05.008.

17. Mermer, A.; Demirbas, N.; Uslu, H.; Demirbas, A.; Ceylan, S.; Sirin, Y. Synthesis of novel Schiff bases using green chemistry techniques; antimicrobial, antioxidant, antiurease activity screening and molecular docking studies. Journal of Molecular Structure 2019, 1181, 412-422, https://doi.org/10.1016/j.molstruc.2018.12.114.

18. Mesbah, M.; Douadi, T.; Sahli, F.; Issaadi, S.; Boukazoula, S.; Chafaa, S. Synthesis, characterization, spectroscopic studies and antimicrobial activity of three new Schiff bases derived from Heterocyclic moiety. Journal of Molecular Structure 2018, 1151, 41-48,https://doi.org/10.1016/j.molstruc.2017.08.098.

19. Miniyar, P.B.; Barmade, M.A.; Mahajan, A.A. Synthesis and biological evaluation of 1-(5-(2chloroquinolin-3-yl)-3-phenyl-1H-pyrazol-1-yl)ethanone derivatives as potential antimicrobial agents. Journal of Saudi Chemical Society 2015, 19, 655-660, https://doi.org/10.1016/j.jscs.2013.12.004.

20. Sriram, D.; Yogeeswari, P.; Basha, J.S.; Radha, D.R.; Nagaraja, V. Synthesis and antimycobacterial evaluation of various 7-substituted ciprofloxacin derivatives. Bioorg Med Chem 2005, 13, 5774-5778, https://doi.org/10.1016/j.bmc.2005.05.063.

21. Ezhilarasi, M.R.; Prabha, B.; Kulandhaivel, M. Green synthesis, spectral characterization and biological activity of novel acetyl pyrazole derivatives. Eur J Pharm.Med.Res2015, 2, 355-369.

22. Bhutani, R.; Pathak, D.P.; Kapoor, G.; Husain, A.; Kant, R.; Iqbal, M.A. Synthesis, molecular modelling studies and ADME prediction of benzothiazole clubbed oxadiazole-Mannich bases, and evaluation of their anti-diabetic activity through in vivo model. Bioorganic Chemistry 2018, 77, 6-15, http://doi.org/10.1016/j.bioorg.2017.12.037.

23. Patil, P.O.; Bari, S.B. An efficient method for the synthesis of isoxazolines under microwave irradiation and solvent-free conditions. Asian J Chem2013, 25, 3588-3590,http://dx.doi.org/10.14233/ajchem.2013.13662.

24. Mohammed, K.S.; Elbeily, E.E.; El-Taweel, F.M.; Fadda, A.A. Synthesis, Characterization, and Antioxidant Evaluation of Some Novel Pyrazolo[3,4-c][1,2]diazepine and Pyrazolo[3,4-c]pyrazole Derivatives. Journal of Heterocyclic Chemistry 2019, 56, 493-500, https://doi.org/10.1002/jhet.3425.

25. Ahmed, S.K.; Ali, W.B.; Khadom, A.A. Synthesis and investigations of heterocyclic compounds as corrosion inhibitors for mild steel in hydrochloric acid. International Journal of Industrial Chemistry 2019, 10, 159-173, https://doi.org/10.1007/s40090-019-0181-8.

26. Habeeb, H.J.; Luaibi, H.M.; Dakhil, R.M.; Kadhum, A.A.H.; Al-Amiery, A.A.; Gaaz, T.S. Development of new corrosion inhibitor tested on mild steel supported by electrochemical study. Results in Physics 2018, 8 , 1260-1267,https://doi.org/10.1016/j.rinp.2018.02.015.

27. Mrani, S.A.; El Arrouji, S.; Karrouchi, K.; El Hajjaji, F.; Alaoui, K.I.; Rais. Z.; Taleb, M. Inhibitory performance of some pyrazole derivatives against corrosion of mild steel in $1.0 \mathrm{M} \mathrm{HCl}$ : Electrochemical, MEB and theoretical studies. Int. J. Corros.Scale Inhib 2018, 4, 542-569,https://doi.org/10.17675/23056894-2018-7-4-5.

28. Lgaz, H.; Salghi, R.; Chaouiki, A.; Shubhalaxmi; Jodeh, S.; Subrahmanya Bhat, K. Pyrazoline derivatives as possible corrosion inhibitors for mild steel in acidic media: A combined experimental and theoretical approach. Cogent Engineering 2018, 5, https://doi.org/10.1080/23311916.2018.1441585.

29. Ferreira, L.L.G.; Andricopulo, A.D. ADMET modeling approaches in drug discovery. Drug Discovery Today 2019, 24, 1157-1165,https://doi.org/10.1016/j.drudis.2019.03.015.

30. Özkan, H.; Adem, Ş. Synthesis, Spectroscopic Characterizations of Novel Norcantharimides, Their ADME Properties and Docking Studies Against COVID-19 $\mathrm{Mpr}^{\circ}$. ChemistrySelect 2020, 5, 54225428,http://doi.org/10.1002/slct.202001123. 
31. Akbar, A.; Mohamed, E.B.; Raza, S.; Wahid, R.; Yeldez, E.K..; El Sayed, H.E.A.; Nawaz, T. Synthesis, Characterization and In-Silico ADMET Screening of Mono-Di-carbomethoxylated 6, 6'-Methylene bis(2cyclohexyl-4-methylphenol) and their Hydrazides and Hydrazones. Der chemical Sinica 2017,8,446-460.

32. Ferreira, L.G.; Dos Santos, R.N.; Oliva, G.; Andricopulo, A.D. Molecular Docking and Structure-Based Drug Design Strategies. Molecules 2015, 20, 13384-13421, https://doi.org/10.3390/molecules200713384.

33. Sharma, D.; Kumar, S.; Narasimhan, B.; Ramasamy, K.; Lim, S.M.; Shah, S.A.A.; Mani, V. 4-(4Bromophenyl)-thiazol-2-amine derivatives: synthesis, biological activity and molecular docking study with ADME profile. BMC Chemistry 2019, 13,https://doi.org/10.1186/s13065-019-0575-x.

34. Muchtaridi, M.; Dermawan, D.;Yusuf, M. Molecular docking 3d structure-based pharmacophore modelling and ADME prediction of alpha mangostin and its derivatives against estrogen receptor alpha. J Young Pharm 2018, 10, 252-259, https://doi.org/10.5530/jyp.2018.10.58.

35. Liao, C.; Sitzmann, M.; Pugliese, A.; Nicklaus, M.C. Software and resources for computational medicinal chemistry. Future Medicinal Chemistry 2011, 3, 1057-1085, https://doi.org/10.4155/fmc.11.63.

36. Sri Dharani, R.; Ranjitha, R.; Sripathi R.; Ali Muhammad, K.S.; Ravi, S. Docking studies in target proteins involved in antibacterial action mechanisms: Alkaloids isolated from Scutellaria genus. Asian J Pharm and Clinical Res 2016, 9, 121-125, http://dx.doi.org/10.22159/ajpcr.2016.v9i5.12693.

37. Krishnakumar, L.;Manju, R.; Andhale, G.; Mathew, P.; Jithu, J.Pass and Swiss ADME collaborated in silico docking approach to the synthesis of certain pyrazoline spacer compounds for dihydrofolate reductase inhibition and antimalarial activity.Bangladesh $J$ Pharmacol 2018, 13, 2329,https://doi.org/10.3329/bjp.v13i1.33625.

38. Talarico, L.B.; Zibetti, R.G.M.; Faria, P.C.S.; Scolaro, L.A.; Duarte, M.E.R.; Noseda, M.D.; Pujol, C.A.; Damonte, E.B. Anti-herpes simplex virus activity of sulfated galactans from the red seaweeds Gymnogongrus griffithsiae and Cryptonemia crenulata. International Journal of Biological Macromolecules 2004, 34, 63-71, https://doi.org/10.1016/j.ijbiomac.2004.03.002.

39. Ali, A.R.; El-Bendary, E.R.; Ghaly, M.A.; Shehata, I.A. Synthesis, in vitro anti-cancer evaluation and in silico studies of novel imidazo[2,1-b]thiazole derivatives bearing pyrazole moieties. European Journal of Medicinal Chemistry 2014, 75, 492-500, https://doi.org/10.1016/j.ejmech.2013.12.010.

40. Mermer, A.; Demirbaş, N.; Şirin, Y.; Uslu, H.; Özdemir, Z.; Demirbaş, A. Conventional and microwave prompted synthesis, antioxidant, anticholinesterase activity screening and molecular docking studies of new quinolone-triazole hybrids. Bioorganic $\quad$ Chemistry 248,248 , https://doi.org/10.1016/j.bioorg.2018.03.017.

41. Daina, A.; Michielin, O.; Zoete, V. SwissADME: a free web tool to evaluate pharmacokinetics, drug-likeness and medicinal chemistry friendliness of small molecules. Scientific Reports 2017, 7, https://doi.org/10.1038/srep42717.

42. Lipinski, C.A.; Lombardo, F.; Dominy, B.W.; Feeney, P.J. Experimental and computational approaches to estimate solubility and permeability in drug discovery and development settings1PII of original article: S0169-409X(96)00423-1. The article was originally published in Advanced Drug Delivery Reviews 23 (1997) 3-25.1. Advanced Drug Delivery Reviews 2001, 46, 3-26, https://doi.org/10.1016/s0169409x(00)00129-0.

43. Muegge, I.; Heald, S.L.; Brittelli, D. Simple Selection Criteria for Drug-like Chemical Matter. Journal of Medicinal Chemistry 2001, 44, 1841-1846, https://doi.org/10.1021/jm015507e.

44. Egan, W.J.; Merz, K.M.; Baldwin, J.J. Prediction of Drug Absorption Using Multivariate Statistics. Journal of Medicinal Chemistry 2000, 43, 3867-3877, https://doi.org/10.1021/jm000292e.

45. Ghose, A.K.; Viswanadhan, V.N.; Wendoloski, J.J. A Knowledge-Based Approach in Designing Combinatorial or Medicinal Chemistry Libraries for Drug Discovery. 1. A Qualitative and Quantitative Characterization of Known Drug Databases. Journal of Combinatorial Chemistry 1999, 1, 5568,https://doi.org/10.1021/cc9800071.

46. Khumar, A.; Kumar, K.; Raja, C.; M.R, E. In-vitro anti-cancer activity, antimicrobial and in-silico studies of naphthyl pyrazole analogues. Rasayan Journal of Chemistry 2020, 13, 1199-1214, http://dx.doi.org/10.31788/RJC.2020.1325495.

47. Manju, M.; Raja, C.; Ezhilarasi, M.R. Synthesis,Characterization, invitro antimicrobial evaluation and insilico molecular docking and ADME prediction of 4-Chlorophenyl furfuran derivatives bearing pyrazole moieties. Asian J Chem 2020, 32, 1482-1490, https://doi.org/10.14233/ajchem.2020.22634.

48. Dhevaraj, J.; Gopalakrishnan, M.; Pazhamalai, S. Synthesis, characterization, molecular docking, ADME and biological evaluation of 3-(4-(tetrazol-1-yl)phenyl)-5-phenyl-1H-pyrazoles. Journal of Molecular Structure 2019, 1193, 450-467,https://doi.org/10.1016/j.molstruc.2019.05.033.

49. Singh, S.; Gupta, A.K.; Verma, A. Molecular properties and bioactivity score of the aloe vera antioxidant compounds - in order to lead finding. Research Journal of Pharmaceutical, Biological and Chemical Sciences 2013, 4, 876-881.

50. Shubhangi; Kumar, N.; Kanagaraj, R.; Lal, K.; Paul, A.K. Modeling molecular interactions of propounded pyrazole based drug candidates against bacterial DNA gyrase: Validation by syntheses and biological studies. Journal of Molecular Structure $2019, \quad$ 1195, https://doi.org/10.1016/j.molstruc.2019.05.125. 